\title{
THE PROVENANCE AND USE OF ETOWAH PALETTES
}

\author{
Vincas P. Steponaitis, Samuel E. Swanson, George Wheeler, and Penelope B. Drooker
}

\begin{abstract}
Based on geological and stylistic evidence, we argue that stone palettes found at Etowah were made locally from nearby raw materials. We also show that they were wrapped in textiles and kept in bundles, i.e., that they were objects used in ritual. Etowah palettes were used as portable altars, perhaps in ceremonies that involved anointing other objects with colorful (and spiritually powerful) substances. The realization that palettes were bundled ritual gear should cause us to rethink common assumptions that such objects moved from site to site by means of "trade," or that they functioned as "prestige goods" in the sense of Frankenstein and Rowlands (1978).
\end{abstract}

De acuerdo con pruebas geológicas y estilísticas, sostenemos que las paletas de piedra encontradas en Etowah fueron hechas localmente a partir de materias primas del área. También demostramos que estas eran envueltas en materias textiles y mantenida en bultos, es decir, que eran objetos utilizados en rituales. Las paletas de Etowah se utilizaban como altares portátiles, quizás en ceremonias que implicaban ungir otros objetos con sustancias coloridas (espiritualmente poderosas). Considerando que las paletas constituían envoltorios rituales, debe hacernos repensar suposiciones comunes de que tales objetos se movían de un sitio a otro por medio del "comercio," o que funcionaban como "bienes de prestigio" en el sentido de Frankenstein y Rowlands (1978).

$\mathrm{S}$ tone palettes, sometimes called "paint palettes" or "sun disks," are distinctive artifacts that have figured prominently in discussions of Mississippian art and iconography. Although palettes have been found over much of the Mississippian world (Webb and DeJarnette 1942:287-291), the vast majority come from only two major centers, Moundville in west-central Alabama and Etowah in northwest Georgia. Over the years the Moundville palettes have been well described (Moore 1905, 1907), their local manufacture has been established (Whitney et al. 2002), and both their style and iconography have been discussed at length (Knight and Steponaitis 2009). The same cannot be said of the Etowah palettes. This paper is intended to mitigate the general lack of published information on Etowah palettes, at least in a preliminary way.
More specifically, we address two basic questions about the Etowah palettes: Where were they made, and how were they used? We approach the first by looking at the style of the palettes and determining the geological provenance, or source, of the raw materials from which they were made. We address the second by examining surface residues and considering in detail the contexts in which these palettes were found. Together, these lines of evidence suggest that the palettes were made locally and were ritual paraphernalia kept in sacred bundles. This conclusion contrasts with a common view of these objects as "paint palettes"-fancy, but essentially utilitarian, tools for grinding pigments-and has implications for how we interpret their presence in burials and more generally at Mississippian centers like Etowah.

The Etowah site is located in Bartow County,

Vincas P. Steponaitis a Research Laboratories of Archaeology, University of North Carolina at Chapel Hill, CB\# 3120, Chapel Hill, North Carolina 27599 -3120 (vin@unc.edu)

Samuel E. Swanson — Department of Geology, University of Georgia, Athens, Georgia 30602 (sswanson@uga.edu) George Wheeler - Department of Scientific Research, Metropolitan Museum of Art, 1000 Fifth Avenue, New York, New York 10028 (George.Wheeler@metmuseum.org)

Penelope B. Drooker $\square$ Research and Collections Division, New York State Museum, 3140 Cultural Education Center, Albany, New York 12230 (pdrooker@mail.nysed.gov) 
Georgia, on the Etowah River just south of Cartersville. It consists of six mounds, large residential areas, and an extensive system of fortifications. The site has a very long history of archaeological investigations, beginning in the 1880s (e.g., King 2003; Larson 1971; Moorehead 1932; Thomas 1894). These investigations have shown that the site's Mississippian occupation spans the centuries from about A.D. 1000 to 1550 . All the palettes that have been found in modern excavations come from contexts assigned to the Late Wilbanks phase, which most scholars believe dates ca. A.D. 1325-1375 (King 2007; cf. Brain and Phillips 1996).

We begin by describing the Etowah palettes and considering their decoration and style in relation to those from Moundville. Next we look in detail at the rocks from which they are made, and correlate these with likely geological sources. We then examine the surface residues and consider the evidence for bundling. Finally, we discuss the implications of these findings regarding how the palettes were used.

\section{General Description}

At least 10 complete palettes have been found at Etowah over the years (Figure 1, Table 1). The first was described by C. C. Jones (1873:373-375), reportedly plowed up in 1859 on the "lower terrace" of Mound A. Three more were collected in the late nineteenth century by Roland Steiner, who is known to have excavated in Mound $\mathrm{C}$ but also may have found them elsewhere at the site (Elliott 2006). One was collected by George Heye sometime before 1915. And five were excavated by Lewis Larson in Mound C during the 1950s (Brain and Phillips 1996:143-164; Kelly and Larson 1957; Larson 1971, 1989). Larson's palettes are the only ones whose archaeological context is known in detail. The ten palettes that comprise our sample are housed in the American Museum of Natural History, the National Museum of Natural History, the National Museum of the American Indian, and the Etowah Indian Mounds Museum, respectively. ${ }^{1}$

These palettes are generally similar in shape, size, and material. Nine are round, range from 23 to $33 \mathrm{~cm}$ in diameter, average about $2.5 \mathrm{~cm}$ in thickness, and are made of a greenish-gray rock (about which more will be said later). The remaining palette is rectangular, 22 by $29 \mathrm{~cm}$ in horizontal dimension, $3 \mathrm{~cm}$ thick, and made of a brown rock. In profile, the palettes generally have tapered edges (Figure 2). The bottoms range from relatively flat to strongly convex. The tops may either be flat or have a sharply depressed area in the center. In short, they are about the size and shape of modern dinner plates, except that they are much thicker and heavier.

All of the objects are decorated the same way, with a scalloped, notched, or rayed edge and a band of one to four lines incised on the top of the rim (Table 2). In addition to the lines, two palettes also have a raised ridge along the rim that forms part of the band. Only one specimen has decoration on the bottom, which consists of a single incised line circling the rim. The incised lines are consistently broad and U-shaped in cross section, typically 2-5 mm wide.

These are common decorative themes in Mississippian art, and they are exactly the same ones found on the palettes from Moundville. The Etowah and Moundville palettes are also very similar in terms of overall size and shape. The fact that both kinds of palettes commonly are found with pigment residues on the surface suggests a similar function (see below).

Despite these similarities, however, the Etowah palettes are very different from the Moundville versions in terms of their style (i.e., the way a design is carried out rather than its content). For example, the incisions on Etowah palettes are broad, while those on Moundville palettes are narrow. In profile, Etowah palettes commonly have features such as rounded or tapered edges, convex bottoms, and depressed centers, while Moundville palettes are almost invariably tabular with squared edges and perfectly parallel faces. When such stylistic differences are coupled with the striking differences in raw material (Moundville specimens are made of a gray micaceous sandstone known to be local to that region), the contrast between the two geographical variants is unmistakable.

In sum, from a purely formal standpoint, the Etowah palettes are thematically similar to the Moundville palettes, but stylistically quite different. The two kinds of palettes were intended for similar purposes but crafted in different workshops, presumably in different places. The question of where the Etowah palettes were made is taken up presently. 

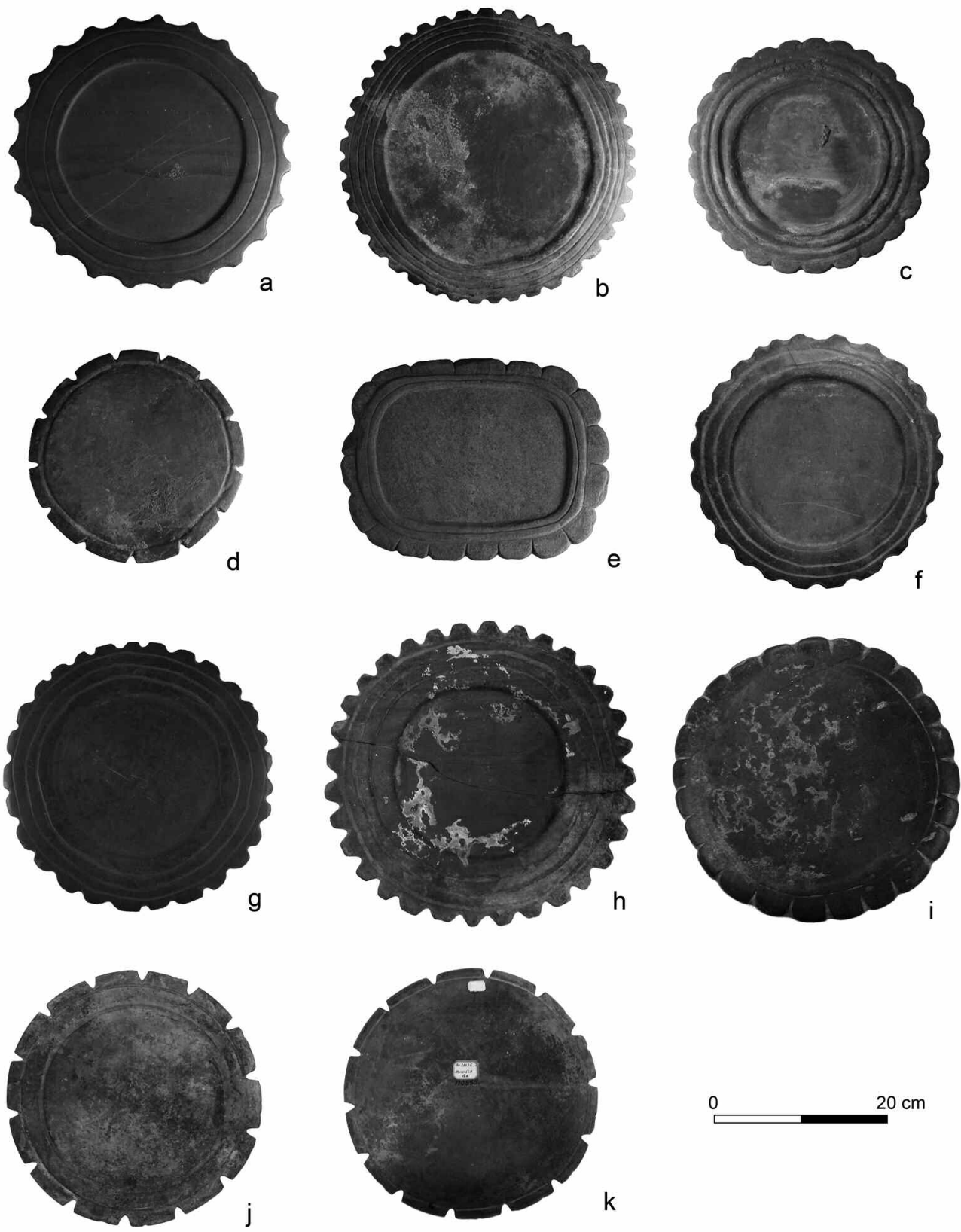

Figure 1. Palettes from the Etowah site: (a) EM-378; (b) EM-482; (c) EM-615; (d) EM-1131; (e) EM-683; (f) AMNH-1; (g) NMAI-1; (h) NMNH-1; (i) NMNH-2; (j) NMNH-3, obverse face; (k) NMNH-3, reverse face. See Table 1 for further information.

\section{Raw Materials and Provenance}

The composition of the rock in the Etowah palettes was determined nondestructively using three methods: hand-sample petrology, X-ray diffraction (XRD), and X-ray fluorescence (XRF). The first two provided data on mineralogy, and the last on geochemistry. All three methods were employed on the five palettes excavated by Larson from Mound C, currently at the Etowah Indian Mounds Museum. Only the first method was applied to the palettes at the National Museum of Natural His- 


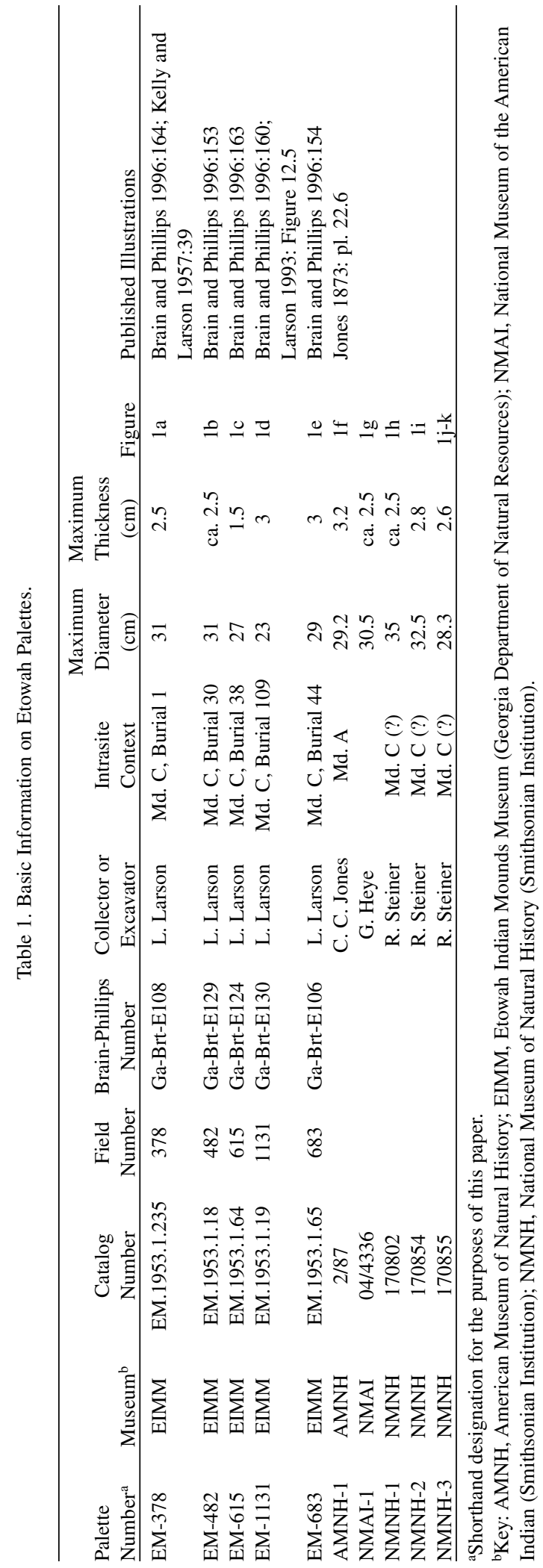



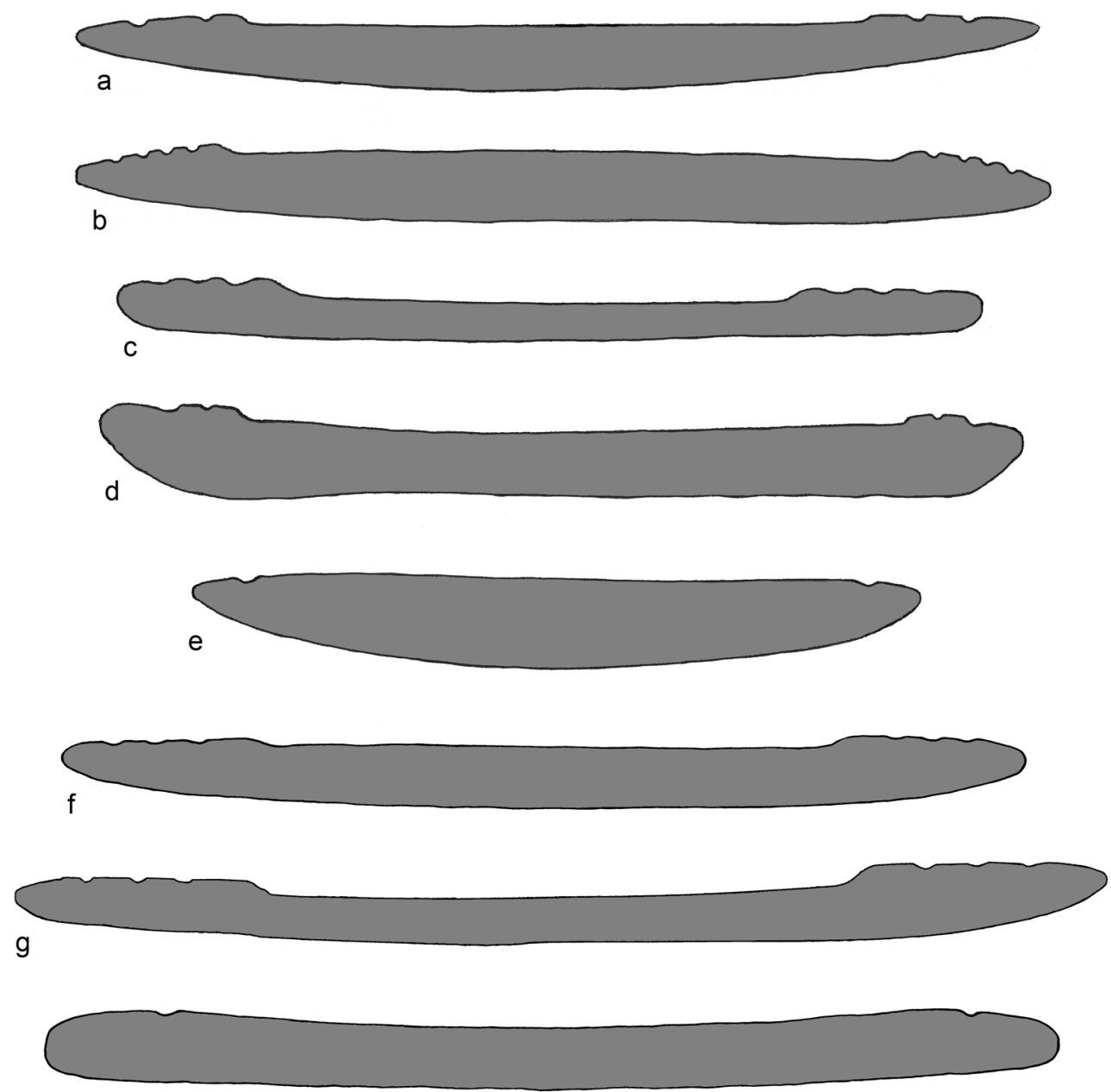

h

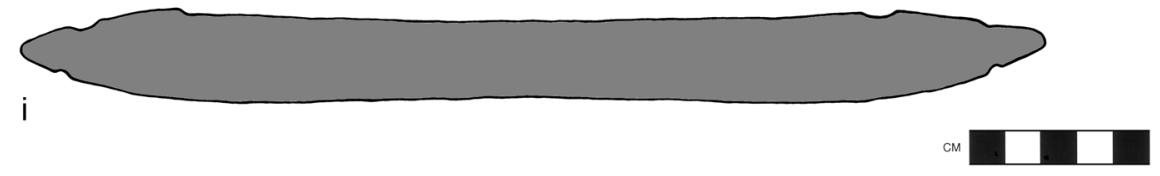

Figure 2. Cross-sections of Etowah palettes: (a) EM-378; (b) EM-482; (c) EM-615; (d) EM-683; (e) EM-1131; (f) NMAI1; (g) NMNH-1; (h) NMNH-2; (i) NMNH-3.

tory and the National Museum of the American Indian.

The hand-sample petrology was carried out by Swanson and involved looking in detail at the surface of the rock with a hand lens and a stereo microscope. Basic mineral properties (e.g., luster, color, cleavage) together with the association (e.g., low grade metamorphic rock) provided clues to mineral identification. This method required a clear view of a polished or freshly broken surface, which was available in all cases, but could only identify the mineral grains large enough to be seen with a low-power microscope.

XRD analysis was performed by Wheeler at the Metropolitan Museum of Art in New York using a Philips 1710 open-architecture diffractometer. Each artifact was placed whole in the sample holder and the X-ray beam directed at a particular point on the surface. Instrument parameters were $40 \mathrm{kV}$ and 30 $\mathrm{mA}$ of $\mathrm{CuK}$ radiation, scanning through 5-65 degrees of Bragg angle. Results were processed using Traces file-manipulation software. Phases 
Table 2. Attributes of Shape and Design on Etowah Palettes.

\begin{tabular}{lcccc}
\hline Palette Number & Shape & Profile & Edge Decoration & Rim Decoration \\
\hline EM-482 & round & depressed center, convex bottom & scalloped & 4 lines on top \\
EM-1131 & round & flat center, convex bottom & notched & 1 line on top \\
EM-615 & round & depressed center, flat bottom & scalloped & 3 lines on top \\
EM-683 & rectangular & flat center, flat bottom & scalloped & 1 ridge on top, 1 line on ridge \\
EM-378 & round & depressed center, convex bottom & rayed & 2 lines on top \\
AMNH-1 & round & depressed center, flat bottom & scalloped & 2 lines on top \\
NMAI-1 & round & depressed center, convex bottom & scalloped & 3 lines on top \\
NMNH-1 & round & depressed center, convex bottom & scalloped & 3 lines on top \\
NMNH-2 & round & flat center, flat bottom & scalloped & 1 line on top \\
NMNH-3 & round & flat center, flat bottom & notched & 2 lines and1 ridge on top, \\
& & & & 1 line on bottom \\
\hline
\end{tabular}

were initially identified with PDSM search-match software, and these preliminary identifications were subsequently refined by Swanson. With openarchitecture XRD, peak intensities may not match powder-diffraction standards perfectly because of preferred grain orientations and variable grain size. Such interpretive difficulties, however, were easily mitigated with a detailed visual examination of the diffraction patterns, coupled with the information gained from the hand-sample petrology. The detection limit with this method was approximately 10 percent. In each case, quartz was used as an internal standard to check the accuracy of the measured diffraction angles.

The XRF analysis was also carried out at the Metropolitan Museum by Wheeler, using a Jordan Valley 3600 open-architecture spectrometer with a lithium-drifted silicon energy-dispersive detector. The measurements were taken nondestructively on the artifact's surface, without special sample preparation, using $10 \mathrm{kV}$ radiation from a rhodium tube and amperage to produce a dead time between 40 and 50 percent. Because the sample was not housed in a vacuum, some lighter elements (such as sodium) could not be detected at all, and the readings for magnesium were unreliable. Nevertheless, the elemental data obtained on silicon ( $\mathrm{Si}$ ), titanium (Ti), aluminum $(\mathrm{Al})$, iron $(\mathrm{Fe})$, calcium $(\mathrm{Ca})$, and potassium $(\mathrm{K})$ were useful, especially when examined as ratios rather than absolute abundances.

Based on their structural characteristics and mineralogy, eight of the palettes appear to be made of the same material: an olive-green-to-gray metasedimentary rock that is best described as a mafic phyllite (Table 3). This rock is fine grained, sometimes shows clear traces of sedimentary bed- ding, and exhibits strong foliation (a type of cleavage caused by metamorphic processes) in a direction at high angles to the bedding. The palettes were carved in a plane parallel to the foliation, which provided natural planes of fracture for making the blanks. The major mineral constituents are chlorite, muscovite, quartz, and albite. The relict bedding contains clastic grains of quartz, as well as altered feldspar and darker, graphitic layers. Weathered pyrite is found in some of the graphitic layers, and veins of barite cut the bedding and foliation in one palette. The presence of quartz and albite in phyllites is consistent with a sedimentary source (siltstone?), while the chlorite and muscovite are consistent with low-grade metamorphism.

A single palette, the rectangular one, is made of a different rock: a light-brown gneiss. It has a granular texture with small grains of albite, quartz, orthoclase, muscovite, and biotite. A vein of feldspar and quartz cross-cuts the foliation at a steep angle. Some accessory garnet crystals are also present. A granitic origin is indicated by the presence of orthoclase, biotite, and garnet. The foliated character of the rock suggests a metamorphic recrystallization of the granite, which may also have produced the garnet. As in other specimens, the palette's faces align with the plane of foliation.

A search of the geological literature and some limited field investigations produced likely local sources for both of these types of rock. The mafic phyllite closely matches rocks typical of the Ocoee Group, which outcrops abundantly in the vicinity of Etowah (Figure 3). The distinctive characteristics of these rocks seen in the palettes include the mineralogy (including the presence of barite veins), 


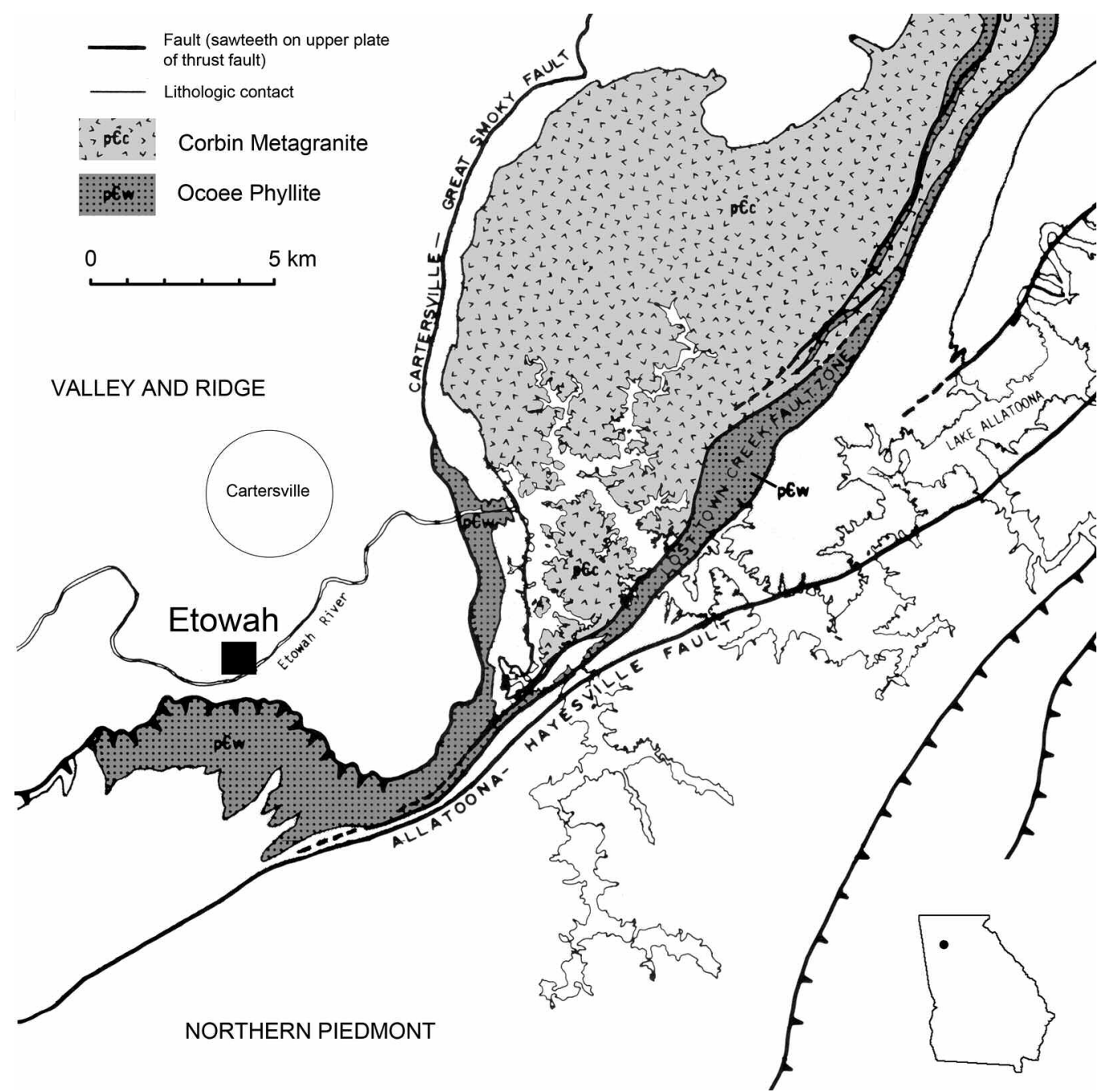

Figure 3. Geological map of the Etowah locality, showing the distribution of Ocoee phyllite and Corbin metagranite deposits (after McConnell and Costello 1984:Figure 3).

the color, the relict bedding, and foliation at high angle to the bedding (Higgins et al. 1988; Kesler 1950).

The gneiss is very similar to rocks of the Corbin metagranite, which also outcrops within a few kilometers of Etowah (Figure 3). The Corbin metagranite varies from a coarse-grained rock with orthoclase megacrysts to a fine-grained foliated metagranite with biotite, muscovite, and garnet (Crickmay 1952). The fine-grained metagranite has the same physical and mineralogical characteristics as the palette in our sample (Costello 1986; Higgins et al. 1988; Martin 1974).

These source identifications are further sup- ported by the data on element concentrations gathered by XRF. These results, recast in terms of oxide components and normalized to 100 percent, are presented in Table 4. The normalization helps to compensate for the lack of data on sodium (which must be present in the albite detected by XRD) and the poor data on magnesium. A side effect of this normalization is that it artificially raises the apparent concentrations of the detected elements relative to their actual concentrations, which must be taken into account when comparing these numbers to the published data (complete chemical analyses by conventional methods) on potential sources. The solution is to compare ratios of elements rather 


\begin{tabular}{|c|c|c|c|c|c|c|c|c|c|c|}
\hline \multirow{2}{*}{$\begin{array}{l}\text { Category: } \\
\text { Palette Number }\end{array}$} & \multirow[b]{2}{*}{ Rock Type } & \multicolumn{8}{|c|}{ Mineral Phase $^{\mathrm{a}}$} & \multirow[b]{2}{*}{ Garnet } \\
\hline & & Albite & Quartz & Chlorite & Orthoclase & Muscovite & Biotite & Pyrite & Barite & \\
\hline \multicolumn{11}{|c|}{ Examined visually and with XRD: } \\
\hline EM-378, dark band & phyllite & $\mathrm{X}$ & & $\mathrm{X}, \mathrm{V}$ & & $\mathrm{X}$ & & $\mathrm{V}$ & $\mathrm{V}$ & \\
\hline EM-378, light band & phyllite & $\mathrm{X}$ & $\mathrm{X}$ & $\mathrm{X}$ & & $\mathrm{X}$ & & & $\mathrm{V}$ & \\
\hline EM-482 & phyllite & $\mathrm{X}, \mathrm{V}$ & $\mathrm{X}, \mathrm{V}$ & $\mathrm{X}$ & & $\mathrm{X}$ & & & & \\
\hline EM-615 & phyllite & $\mathrm{X}$ & $\mathrm{X}, \mathrm{V}$ & $\mathrm{X}$ & & $\mathrm{X}, \mathrm{V}$ & & $\mathrm{V}$ & & \\
\hline EM-1131 & phyllite & $\mathrm{X}, \mathrm{V}$ & $\mathrm{X}, \mathrm{V}$ & $\mathrm{X}$ & & $\mathrm{X}$ & & $\mathrm{V}$ & & \\
\hline EM-683 & gneiss & $\mathrm{X}, \mathrm{V}$ & $\mathrm{X}, \mathrm{V}$ & & $\mathrm{X}$ & $\mathrm{X}$ & $\mathrm{V}$ & & & $\mathrm{V}$ \\
\hline \multicolumn{11}{|l|}{ Examined only visually: } \\
\hline NMAI-1 & phyllite & & $\mathrm{V}$ & & & $\mathrm{V}$ & & & & \\
\hline NMNH-1 & phyllite & V & $\mathrm{V}$ & V & & $\mathrm{V}$ & & & & \\
\hline NMNH-2 & phyllite & V & V & & & $\mathrm{V}$ & & V & & \\
\hline NMNH-3 & phyllite & & $\mathrm{V}$ & & & $\mathrm{V}$ & & & & \\
\hline
\end{tabular}

a Key: X, identified by X-ray diffraction; V, identified by visual inspection (handsample petrology).

Table 4. Chemical Composition of Etowah Palettes.

\begin{tabular}{|c|c|c|c|c|c|c|c|c|c|c|}
\hline \multirow[b]{2}{*}{ Palette Number } & \multirow[b]{2}{*}{ Rock Type } & \multicolumn{9}{|c|}{ Normalized Percentages } \\
\hline & & $\mathrm{SiO}_{2}$ & $\mathrm{TiO}_{2}$ & $\mathrm{Al}_{2} \mathrm{O}_{3}$ & $\mathrm{FeO}^{\mathrm{a}}$ & $\mathrm{MnO}$ & $\mathrm{MgO}$ & $\mathrm{CaO}$ & $\mathrm{K}_{2} \mathrm{O}$ & Total \\
\hline EM-378, dark band & phyllite & 56.70 & 0.86 & 22.11 & 11.27 & 0.12 & 6.26 & 0.45 & 2.23 & 100 \\
\hline EM-378, light band & phyllite & 58.88 & 1.24 & 22.02 & 8.36 & 0.10 & 5.87 & 0.53 & 3.00 & 100 \\
\hline EM-482 & phyllite & 58.38 & 1.48 & 24.16 & 11.36 & & & 0.71 & 3.91 & 100 \\
\hline EM-615 & phyllite & 62.01 & 1.59 & 23.05 & 8.97 & 0.07 & & 0.61 & 3.70 & 100 \\
\hline EM-1131 & phyllite & 59.57 & 1.26 & 27.07 & 8.69 & 0.14 & & 1.36 & 1.42 & 100 \\
\hline EM-683 & gneiss & 77.51 & 0.51 & 16.10 & 2.98 & 0.18 & & 1.25 & 1.35 & 100 \\
\hline
\end{tabular}

${ }^{\text {aTotal }} \mathrm{Fe}$ as $\mathrm{FeO}$. 


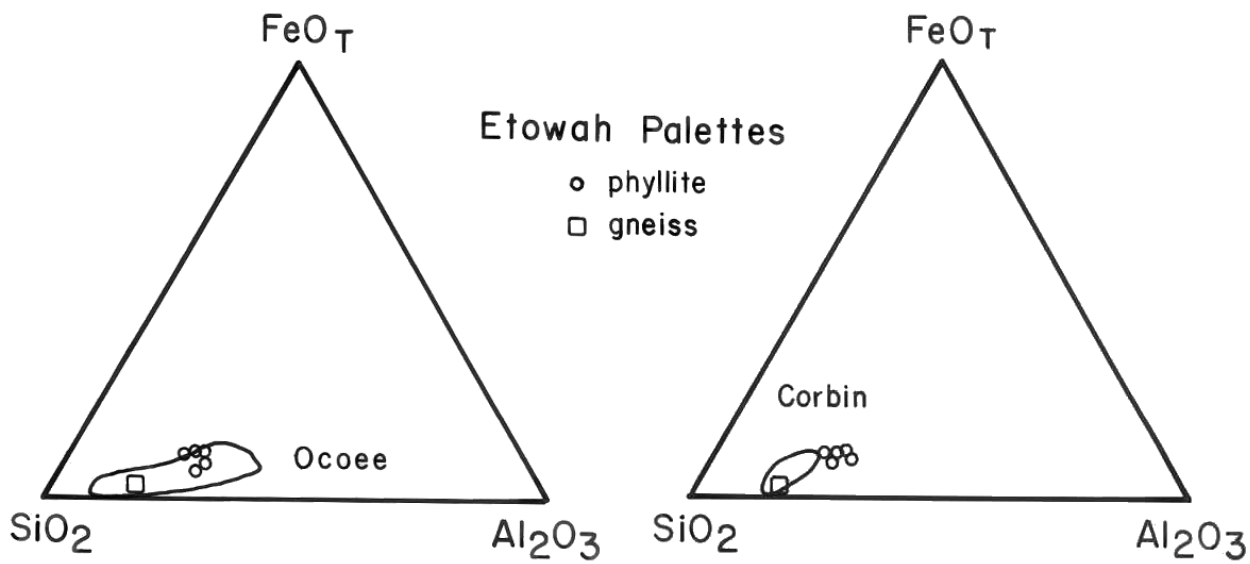

Figure 4. Triangular plot of iron (Fe), aluminum (Al), and silicon (Si) oxides for Etowah palettes, compared with published values for Ocoee phyllite and Corbin metagranite. Palette data from Table 4; Ocoee and Corbin data from Kesler (1950), Higgins et al. (1988) and Martin (1974).

than absolute abundances, which can easily be done with triangular diagrams.

There are two groups of constituents among the elements separated by an order-of-magnitude difference in abundance (Table 4). Major constituents, generally present in amounts greater than 10 percent (by weight), include iron (total Fe represented as $\mathrm{FeO}$ ), silicon ( $\mathrm{Si})$, and aluminum ( $\mathrm{Al})$. These account for more than 80 percent of each analysis. Minor constituents, present in amounts of less than 5 percent, include titanium $(\mathrm{Ti})$, calcium $(\mathrm{Ca})$, and potassium (K).

A triangular diagram of Fe-Al-Si shows an overall clustering of Etowah palettes near the Si corner
(Figure 4). The phyllite palettes plot in a tight cluster while the gneiss palette plots at higher Si. Note that the Etowah phyllite palettes generally fall within the compositional field defined by published analyses of Ocoee Group phyllites, and the gneiss palette falls within the rather tight field defined for the Corbin Group metagranites.

The triangular diagram of Ti-Ca-K shows a cluster of three phyllite palettes, with one phyllite palette (1131) and the gneiss palette as outliers (Figure 5). The cluster of phyllite palettes falls on the edge of the Ocoee phyllite field, while the gneiss palette falls squarely within the Corbin metagranite field. Thus, except for the one phyllite palette
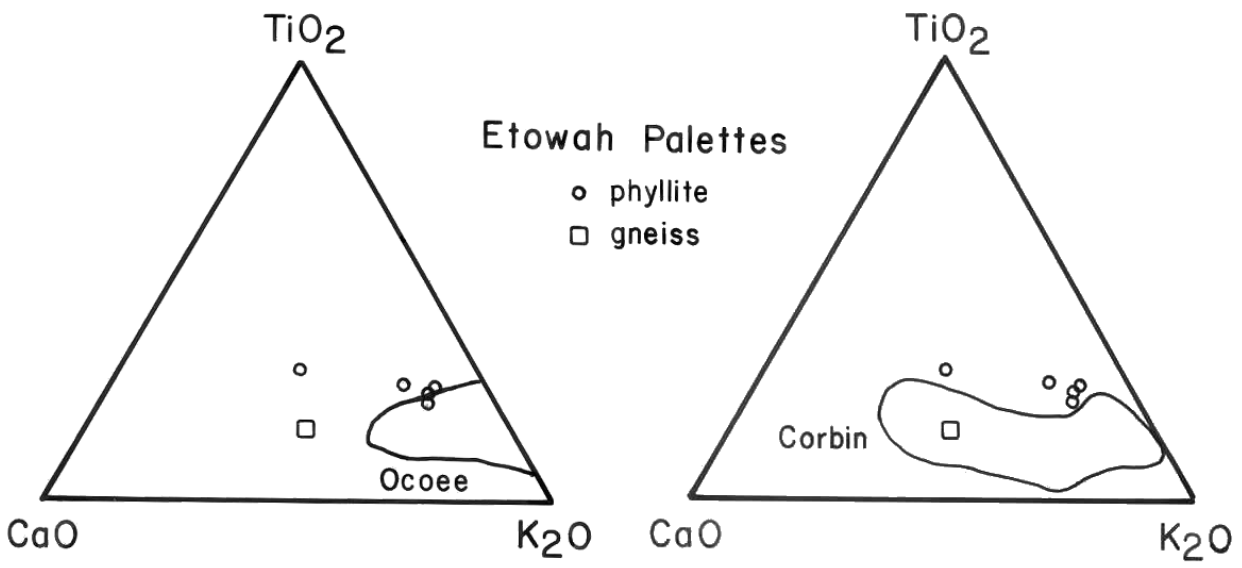

Figure 5. Triangular plot of titanium (Ti), calcium (Ca), and potassium (K) oxides for Etowah palettes, compared with published values for Ocoee phyllite and Corbin metagranite. Palette data from Table 4; Ocoee and Corbin data from Kesler (1950), Higgins et al. (1988), and Martin (1974). 
Table 5. Surface Residues on Etowah Palettes.

\begin{tabular}{|c|c|c|c|c|c|c|c|}
\hline \multirow[b]{2}{*}{$\underline{\text { Palette Number }}$} & \multirow[b]{2}{*}{ Rock Type } & \multicolumn{5}{|c|}{ Surface Residue $^{a}$} & \multirow[b]{2}{*}{ Resin } \\
\hline & & Kaolinite & Calcite & Hematite & Graphite & Galena $^{\mathrm{b}}$ & \\
\hline EM-482 & phyllite & V? & X & V & V? & $\mathrm{F}$ & V \\
\hline EM-615 & phyllite & V & & V & V & $\mathrm{F}$ & V \\
\hline EM-1131 & phyllite & V & & V & V? & $X$ & $\mathrm{~V}$ \\
\hline
\end{tabular}

${ }^{\mathrm{a}} \mathrm{Key}$ : X, identified by X-ray diffraction; F, identified by X-ray fluorescence; V, identified by visual inspection (handsample petrography). Question mark indicates an uncertain identification.

${ }^{\mathrm{b}}$ This category also includes weathering products of galena such as cerrusite, anglesite, and pyromorphite. These are detected in XRF by the presence of lead, in XRD by the specific phase (pyromorphite in EM-1131).

with a lower-than-expected $\mathrm{K}$ value, the fit with the Ocoee and Corbin sources is quite good.

In sum, both the mineralogical and chemical data suggest that the Etowah palettes were made of locally available rocks, a conclusion that was anticipated, albeit not supported by detailed geological analysis, many years ago by Larson (1971:64, 1989:140). We therefore argue that these palettes were probably crafted in the Etowah region.

\section{Surface Residues}

Moore noted over a century ago that stone palettes at Moundville were typically found with mineral pigments adhering to their surfaces, typically on the top (obverse) side (Moore 1905:145-147, 1907:392). The same is true of the palettes at Etowah. Most palettes in museum collections have been subjected to a thorough cleaning, which has removed all but the most tenacious residues or those trapped in crevices. We are fortunate in this case, however, that three of the palettes found by Larson during his excavations in Mound $\mathrm{C}$ were cleaned very lightly so as to preserve the adhering residues. Larson's foresight in treading lightly on these residues now provides a valuable opportunity to learn more about the ways in which these palettes were used.

The residues on these three palettes were examined with the same nondestructive techniques used to assess the composition of the palettes themselves. In so doing we recognized at least seven different substances resting on the palettes' surfaces: kaolinite, calcite, hematite, graphite, galena, and an organic resin (Table 5). A brief description of each follows.

Kaolinite. This is a clay mineral that is pure white in color. In each case it was identified visu- ally. In some places it contained small grains of mica and quartz.

Calcite. Visually this appeared as a white powdery substance, without other mineral inclusions. The mineral identification was confirmed by XRD. One likely source for this substance would have been burned mussel shells. Such shells typically consist of aragonite, but when heated this mineral alters to calcite and becomes very friable and easy to crush.

Hematite. This mineral was identified visually by its bright-red color. It occurs either in the form of red ochre or as a hematite-rich clay.

Graphite. This black pigment consists of mineralized carbon and was identified visually. It appears in the form of glossy black crystals, sometimes mixed with the kaolinite or other residues.

Galena. This is a crystalline lead ore with a shiny, silvery appearance. When weathered, it turns into cerrusite (a white substance), anglesite (typically gray-white), or pyromorphite. XRF detected galena or its derivatives on two palettes by the presence of lead. XRD picked up pyromorphite on the third palette. In each case, galena crystals were also identified visually.

Resin. This substance is yellowish-brown in color and sometimes covers large areas on the palette, often with white pigments underneath. When viewed under magnification, it exhibits a "bubbly" or botryoidal texture that clearly indicates it was once a fluid or viscous material that later hardened. This may be a plant resin, but we are by no means certain, as neither XRD nor XRF is capable of identifying its composition.

Sometimes these residues appear in what seem to be pure deposits of a single substance. In other cases they appear to be mixed, as on palette EM-615, much of whose surface was covered by 
Table 6. Objects Bundled with Etowah Palettes.

\begin{tabular}{|c|c|c|c|c|}
\hline $\begin{array}{r}\text { Context: } \\
\text { Object }\end{array}$ & $\begin{array}{c}\text { Field } \\
\text { Number }\end{array}$ & $\begin{array}{c}\text { Position in } \\
\text { Burial }\end{array}$ & $\begin{array}{c}\text { Material } \\
\text { Identification } \\
\text { Method }^{\mathrm{a}} \\
\end{array}$ & Comment \\
\hline \multicolumn{5}{|l|}{ Mound C, Burial 30: } \\
\hline Phyllite palette (EM-482) & 482 & above skull & $\mathrm{V}, \mathrm{X}, \mathrm{F}$ & found upside down \\
\hline Galena pebble & 482 & under palette & $\mathrm{V}, \mathrm{X}, \mathrm{F}$ & \\
\hline Hematite mass & 483 & under palette & $\mathrm{V}$ & \\
\hline Calcite ("shell") mass & & under palette & & not in collections; described in field notes \\
\hline Small pebbles & & under palette & & not in collections; described in field notes \\
\hline \multicolumn{5}{|l|}{ Mound C, Burial 38: } \\
\hline Phyllite palette (EM-615) & 615 & between skulls 1,2 & $\mathrm{~V}, \mathrm{X}, \mathrm{F}$ & found upside down \\
\hline Galena pebble & 616 & under palette & $\mathrm{V}, \mathrm{X}, \mathrm{F}$ & \\
\hline Graphite pebble & 617 & under palette & $\mathrm{V}, \mathrm{X}, \mathrm{F}$ & \\
\hline \multicolumn{5}{|l|}{ Mound C, Burial 44: } \\
\hline Gneiss palette (EM-683) & 683 & near feet & $\mathrm{V}, \mathrm{X}, \mathrm{F}$ & found upside down \\
\hline Specular hematite "reel" & 685 & beside palette & $\mathrm{V}, \mathrm{X}, \mathrm{F}$ & misidentified in field drawing as galena \\
\hline Specular hematite pebble & 696 & beside palette & $\mathrm{V}, \mathrm{X}, \mathrm{F}$ & may have been part of larger hematite mass \\
\hline 4 turtle-shell batons & 670 & beside palette & & description from field notes and catalog \\
\hline \multicolumn{5}{|l|}{ Mound C, Burial 109: } \\
\hline Phyllite palette (EM-1131) & 1131 & beside right arm & $\mathrm{V}, \mathrm{X}, \mathrm{F}$ & found right side up \\
\hline Galena pebble & 1111 & near right wrist & $\mathrm{X}$ & presumably near palette, but not on it \\
\hline Hematite & 1127 & on top of palette & & not in collections; described in field notes \\
\hline Hematite & 1132 & on top of palette & & not in collections; described in field notes \\
\hline Kaolinite mass & 1136 & (not specified) & $\mathrm{X}$ & field number suggests it was near palette \\
\hline Cloth, copper & 1133 & under palette & & not in collections; described in field notes \\
\hline
\end{tabular}

Note: Information obtained from the field and museum records of the Georgia Department of Natural Resources, housed at the Antonio J. Waring, Jr. Archaeological Laboratory, University of West Georgia, Carrollton.

aThe raw materials were identified by Swanson and Wheeler using the methods listed in this column. Where no method is listed, the identification is from the field and accession records. Key: X, identified by X-ray diffraction; F, identified by Xray fluorescence; $\mathrm{V}$, identified by visual inspection (handsample petrography).

a deposit of white kaolinite containing small flakes of black graphite. The incisions on a palette's rim tend to contain thicker deposits, which often are layered with different colors, suggesting repeated episodes of use. In general, it looks as though the center of the palette retained residues from the most recent episodes, while the incisions along the edge were less likely to be cleaned or disturbed and thus accumulated thicker, stratified deposits.

Finally, it should be noted that even the heavily cleaned palettes from Etowah usually show at least some traces of red, white, or black pigments, as well as the brown resin. This gives us reason to believe that all the palettes originally had such residues. Apart from noting their presence, however, we undertook no further analysis of the pigments on these other palettes.

\section{Evidence for Bundling}

Larson's excavations in Mound $\mathrm{C}$ provided strong evidence that the palettes were consistently placed in bundles, that is, they were kept in "kits" with other objects and wrapped with textiles. The five palettes recovered in these excavations were all found in burial features. One of these contexts, Burial 1 , was actually a "midden-like smear of human bone and other objects" that appear to have been thrown down the flank of the mound, perhaps by invaders who pillaged the summit temple (Dye and King 2007:173-176; King 2003:80; also see Brain and Phillips 1996:163-164; Larson 1971:65). By virtue of its haphazard deposition, this feature is of little help in interpreting how the palettes were typically buried. The other four features, however, are much more informative (Table 6).

Burial 30 was an adult of indeterminate sex who was placed in a log-lined pit (Brain and Phillips 1996:153). ${ }^{2}$ The excavators found some shell beads and mica ornaments near the legs, and a palette (EM-482) above the skull. The palette was turned upside down with a number of objects directly underneath: a galena pebble, a mass of hematite (red ochre), some calcite (described in the field 


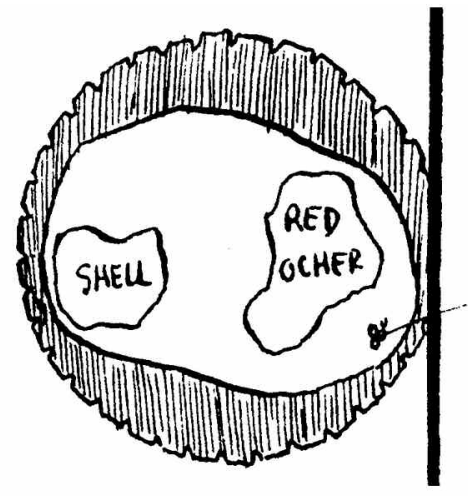

a

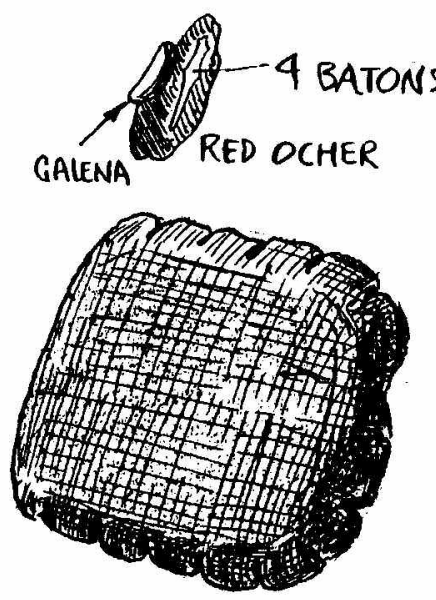

C

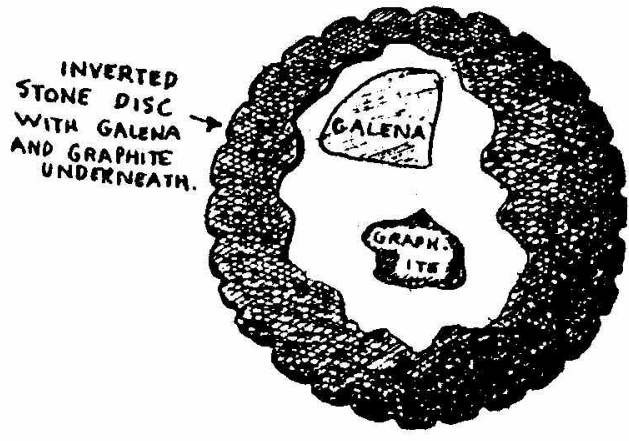

b

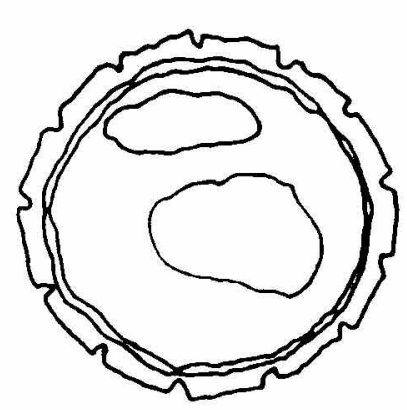

d

Figure 6. Field drawings of palettes and associated artifacts from Mound C, Etowah, showing the finds in situ: (a) palette EM-482 in Burial 30; (b) palette EM-615 in Burial 38; (c) palette EM-683 in Burial 44; (d) palette EM-1131 in Burial 109 (after Larson 1993:Figure 12.2). Palettes (a) and (b) were found inverted and are drawn with cutaways showing items beneath. The specular hematite reel in (c) was misidentified in the field and is labeled in the drawing as "galena." Drawings (a)-(c) by George Stuart; (d) by Genzadela Lopez.

notes as "shell" but apparently not recovered), and a cluster of small pebbles (Table 6; Figures 6a, 7). The positions of the hematite and calcite in the field drawing correspond to the areas of the palette's surface where similar residues occur. There is a blank area in the residues where the galena rested against the palette, and the galena itself was partly covered with similar residues. All this indicates the intimate association between the palette and the objects underneath.

Burial 38 was a log-lined tomb that contained the remains of five females in their late teens and early 20s (Brain and Phillips 1996:162-163; King
2003:75-76; Larson 1971:65). Each was buried with copper-covered wooden ear disks and a copper axe. Four wore elaborate headdresses ornamented with copper and feathers, and the fifth was accompanied by a palette (EM-615). Again, the latter was found upside-down, resting on a galena pebble and a graphite pebble, both of which were in direct contact with the palette's obverse face (Table 6; Figures 6b, 8). The tightness of this association, quite literally, can be seen in the residues on the palette, which outline a "shadow" in the shape of each pebble where it touched the palette's surface, as if they were pressed together. 


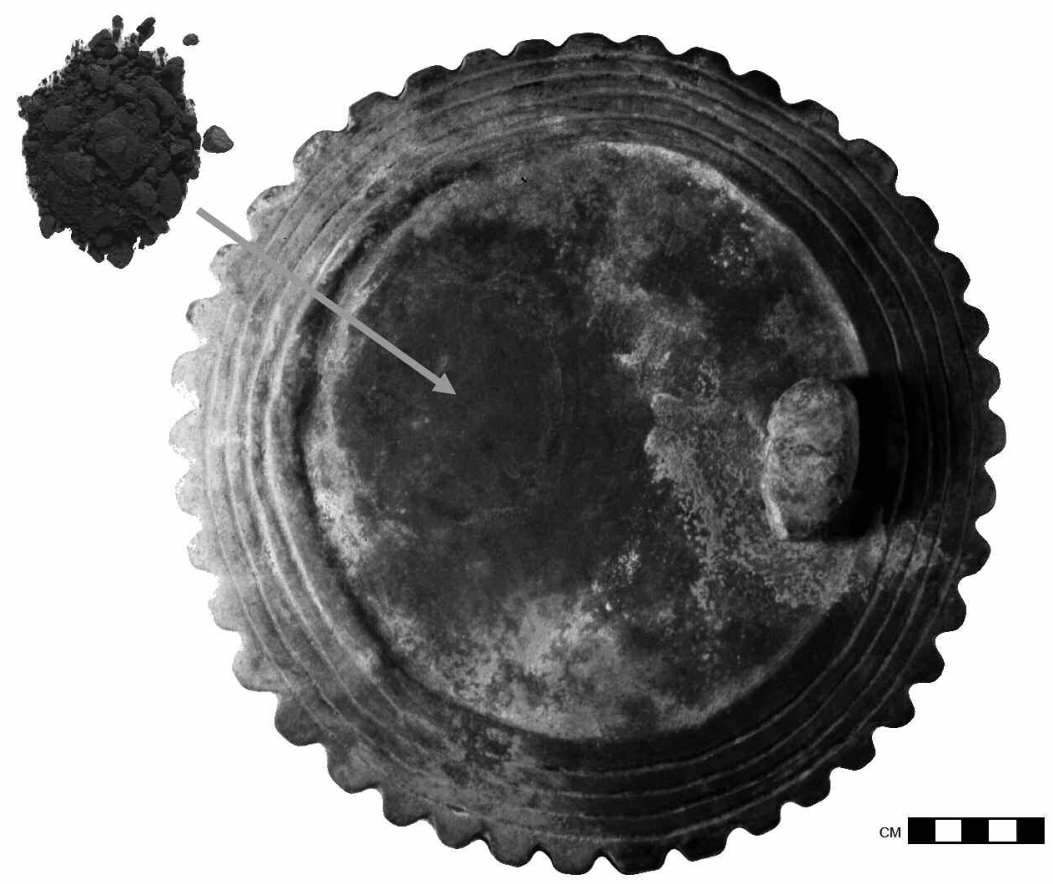

Figure 7. Palette EM-482 and associated artifacts, Burial 30. Galena pebble (right) is placed where it was found in situ against the obverse face of the palette; arrow indicates where the hematite mass (on left) was found. Note that the outline of the area that contained the hematite is visible on the palette's surface.

Burial 44 consisted of an adult male placed in a simple pit (Brain and Phillips 1996:154). Three chunkey stones, two stone celts, and a clay pipe were placed near the head and chest. At the feet were two conch-shell cups, shell beads, mica crosses, and two masses of green pigment. Next to the feet was found an inverted stone palette (EM683 ), and just to one side of the palette was a tight cluster of objects including a piece of specular hematite ground into the shape of a "reel," a rough specular hematite pebble together with some red ochre, and four small "batons" made of tortoise shell (Table 6; Figures 6c, 9). Unlike the cases just described, these objects were not in direct contact with the palette, but their proximity and alignment strongly suggest an association.

Burial 109 was placed in a large pit, 3 m deep, with wooden posts along one side. It contained the badly decayed remains of at least one adult male, whose bones had been somewhat scattered within the pit (Brain and Phillips 1996:160-161; Larson 1993:172-179). The inventory of grave items includes shell beads, copper ear disks, a copper bilobed-arrow headdress, many other copper ornaments, a monolithic axe, a copper axe, a tortoiseshell pin and other ornaments, and a stone palette (EM-1131). Unlike the others, this palette was found right side up, on the right arm. The field notes describe two hematite masses on the palette, and "cloth, copper, etc." beneath it (Table 6; Figures $6 \mathrm{~d}, 10)$. A galena pebble is listed in the field notes as being "near right wrist," which would have placed it very close to the palette. Larson, in his published description of the burial, says the galena was found on the tablet (Larson 1993:174). Also found in the burial was a mass of pure-white kaolinite. Its location is not explicitly stated in the notes. However, its position in the sequence of field numbers suggests it was found near the palette, and the palette does have kaolinite residues on its surface. It is worth noting that three small cubes of galena were also found near the feet, far from the items associated directly with the palette.

The pattern in all these cases is consistent: each palette was found tightly clustered with a metallic pebble (galena or specular hematite) and one 


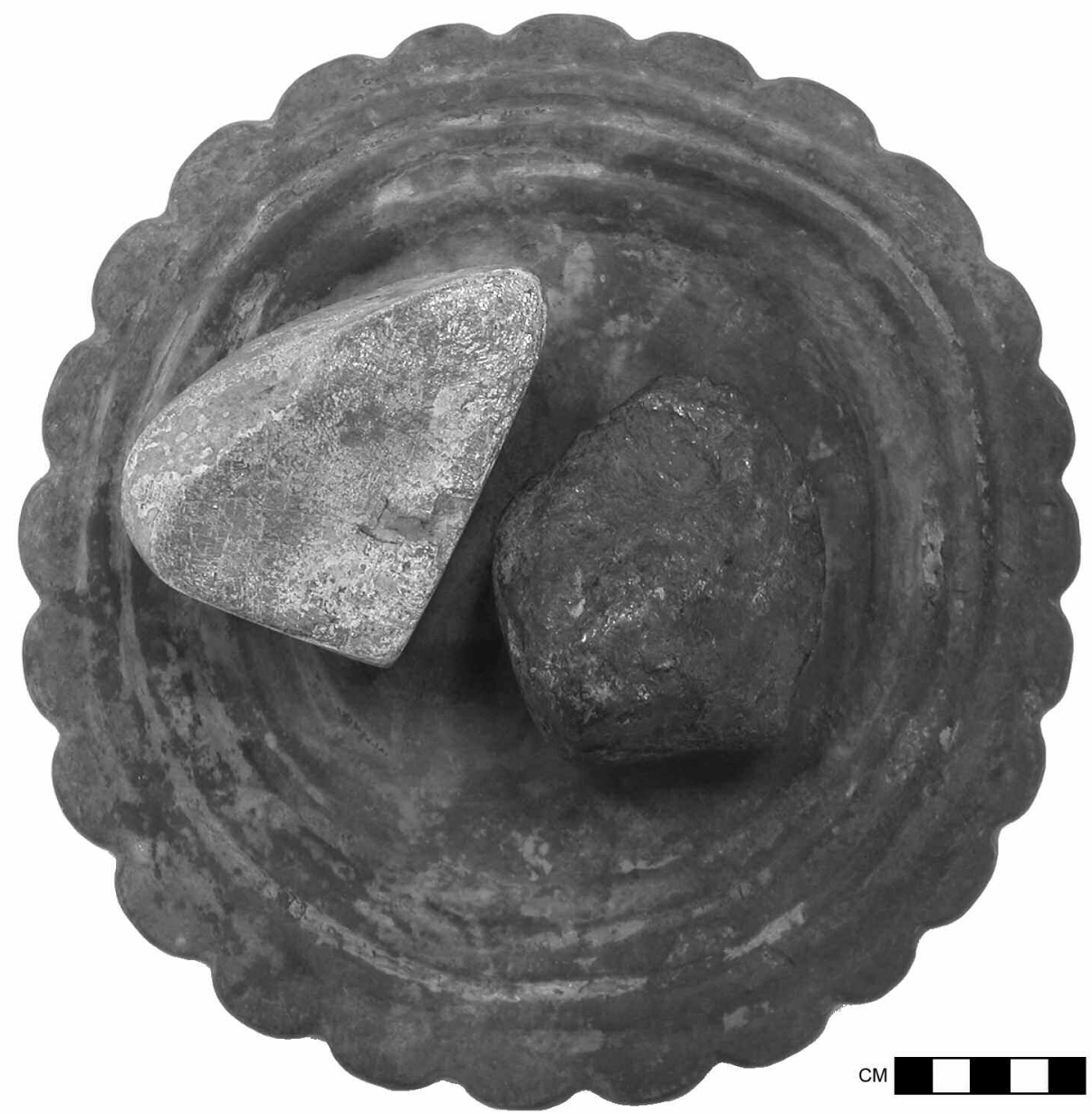

Figure 8. Palette EM-615 and associated artifacts, Burial 38. Galena pebble (left) and graphite lump (right) are placed on the obverse face of the palette as they were found in situ.

or more masses of mineral pigment. The latter could be white (kaolinite or calcite), red (hematite), or black (graphite) in color. In two cases the galena and mineral pigments rested directly against the top (obverse) surface of the palettes, in the same relative positions, even though the palettes were placed in the ground upside down. In other words, the contexts give every appearance that the palettes, metallic pebbles, and mineral pigments were bundled together at the time they were placed in the graves.

Additional evidence of bundling was found in the form of textile impressions on the reverse sides of four palettes (Figure 11), including all those that were lightly cleaned. These impressions appear on the stone as discolorations, which are sometimes mirrored in the lighter-colored soil adhering to the surface. How these discolorations were formed is unclear and will remain so until further studies are undertaken. We suspect, but cannot demonstrate, that they were produced by a chemical alteration of the surface that occurred as the fabric decayed (cf. Gordon 1997:20; Robinson 1996:119, Figures 17-18; Whitehead 1987). In each case, the impressions cover most of the bottom and continue around the rim, clearly indicating that they represent wrappings or bags, rather than flat layers of cloth on which the palettes sat. The absence of textile impressions on the top face of each palette presumably resulted from the presence of pigments 

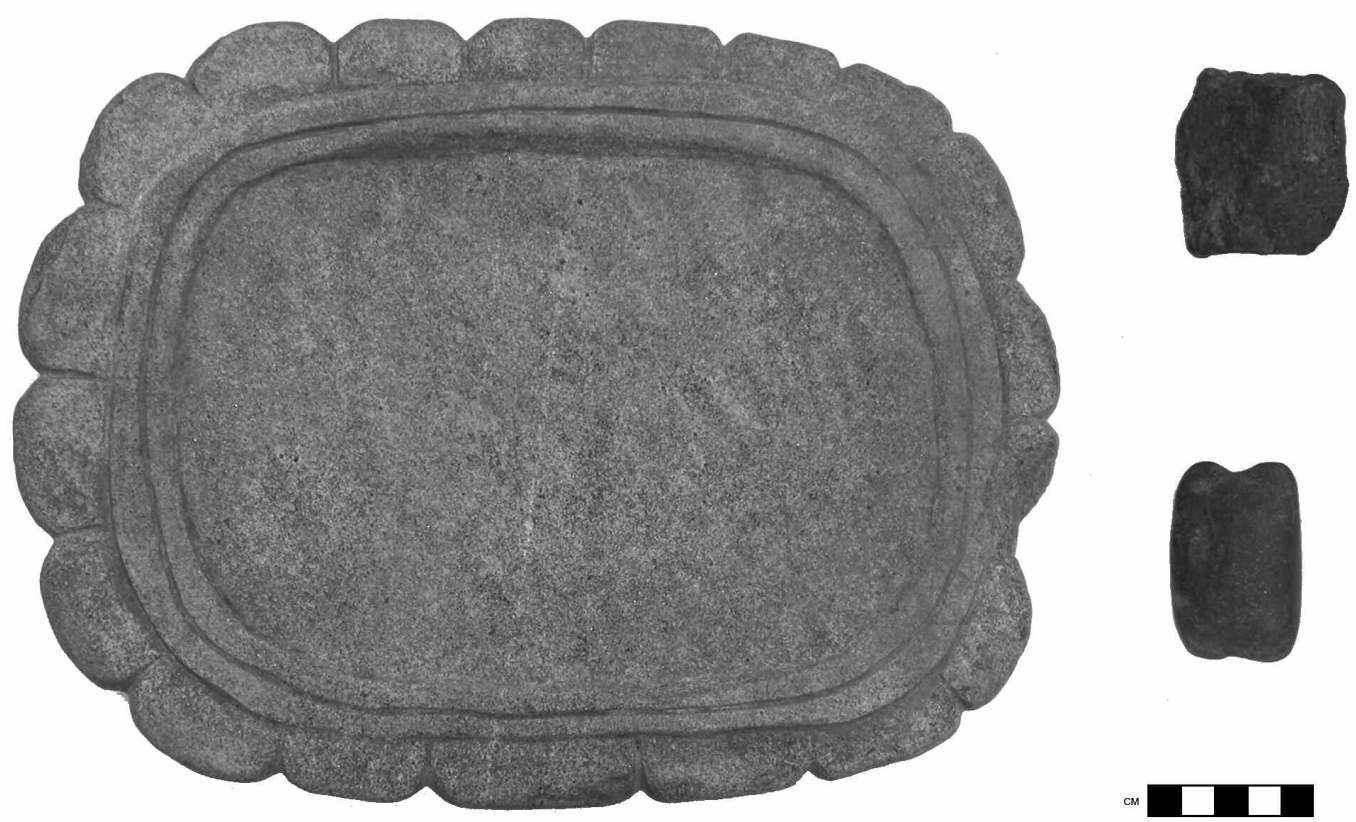

Figure 9. Palette EM-683 and associated artifacts, Burial 44. Specular hematite "reel" (bottom right) and specular hematite lump (upper right) were found next to the palette, along with a set of small tortoise-shell batons (not pictured).

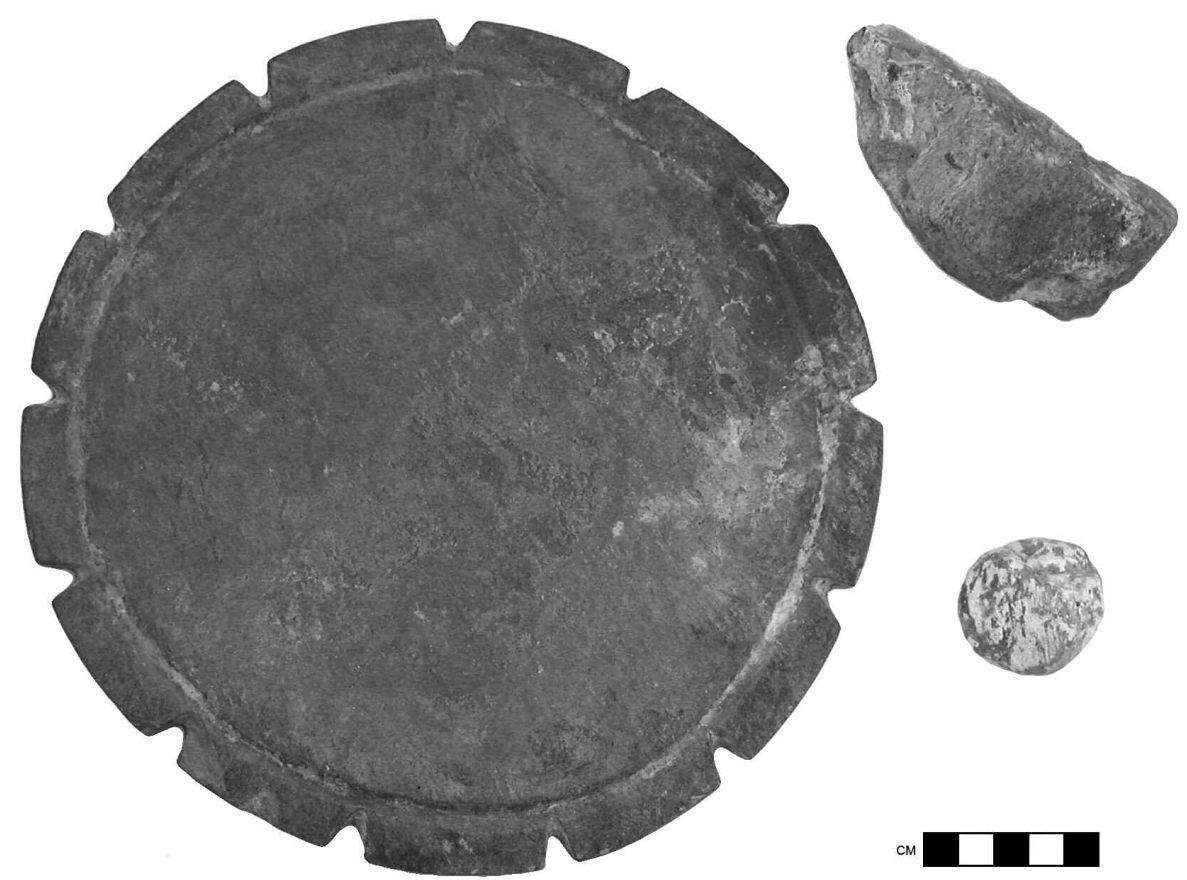

Figure 10. Palette EM-1131 and associated artifacts, Burial 109. Galena pebble (upper right) was found on or near this palette. Kaolinite lump (lower right) was found in the same burial, also probably close to the palette. 


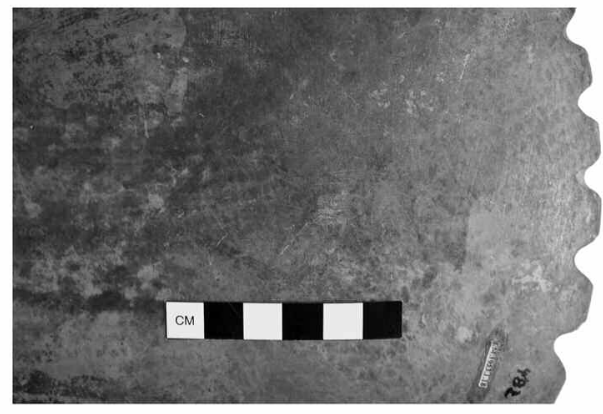

a

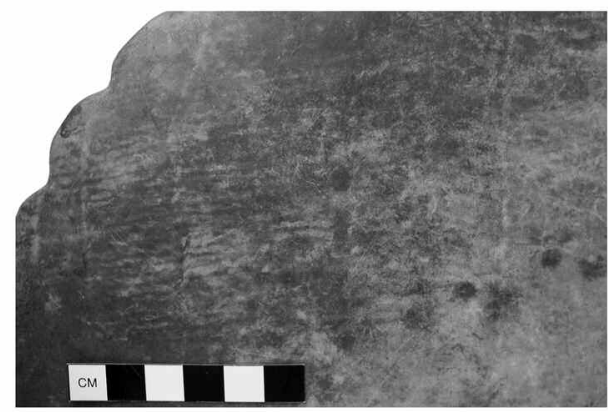

C

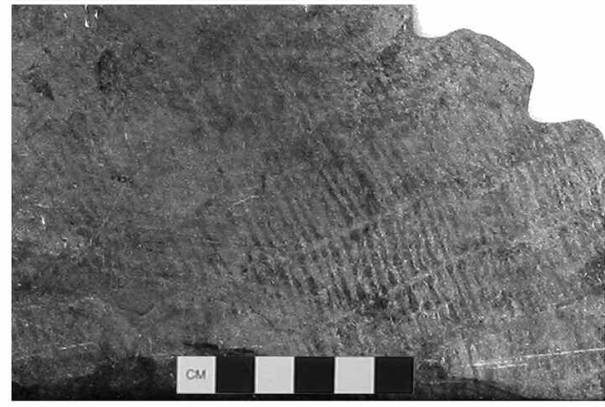

e

and other objects on that surface, which prevented the textile from coming into contact with it.

The textile impressions were studied in detail and measured by Drooker (Table 7). The fabrics were not standardized. Five distinct fabrics are visible (two of them on palette EM-482), representing three different structures: plain twining, alternate pair twining, and plain twining with interlinked warps, also called "octagonal openwork" twining (Miner 1936:187). They also differ considerably in quality. The plain-twined fabric EM-1131/1, with its thick and inconsistent yarns, coarse scale, and simple structure, is the

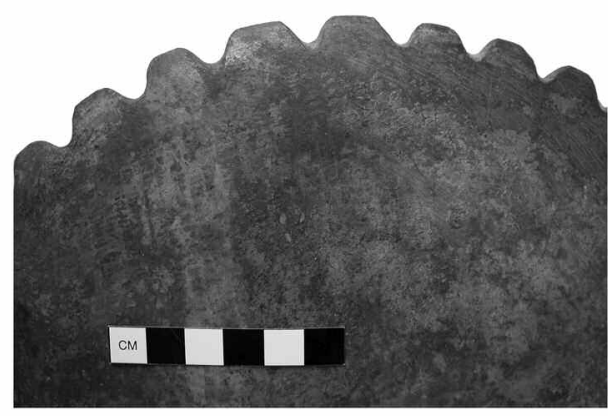

b

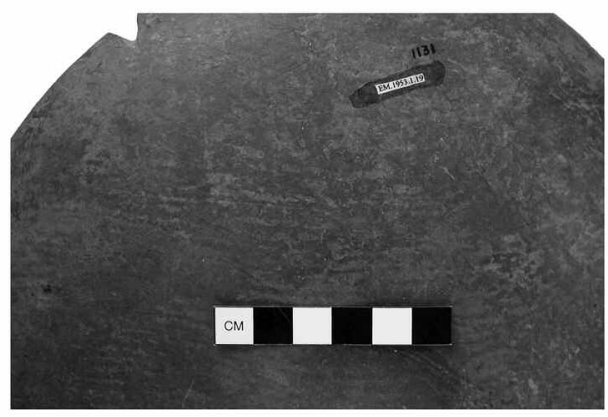

d

Figure 11. Textile impressions on Etowah palettes (reverse face): (a) EM-482/1, alternate-pair-twined fabric, twining rows approximately horizontal; (b) EM-482/2, fabric combining plain twining and interlinked warp pairs ("octagonal openwork" twining), weft rows approximately vertical, warp yarns run parallel to rim; (c) EM-615/1, plaintwined fabric, warp yarns horizontal; (d) EM-1131/1, plain-twined fabric, warp yarns horizontal; (e) NMNH$1 / 1$, plain-twined fabric, warp yarns roughly parallel to rim.

least elaborate. The similar fabric NMNH-1/1, although relatively coarse, has more uniform yarns indicating a higher level of craftsmanship. The octagonal-openwork textile EM-482/2, with the highest fabric count, thinnest yarns, and structural decoration, represents the most laborintensive and sophisticated product. ${ }^{3}$ All five textiles are fairly open, that is, not opaque. A single layer of such fabric would poorly conceal any object around which it was wrapped, which suggests that there may have been additional layers of covering, perhaps even of other materials such as basketry or hide. 


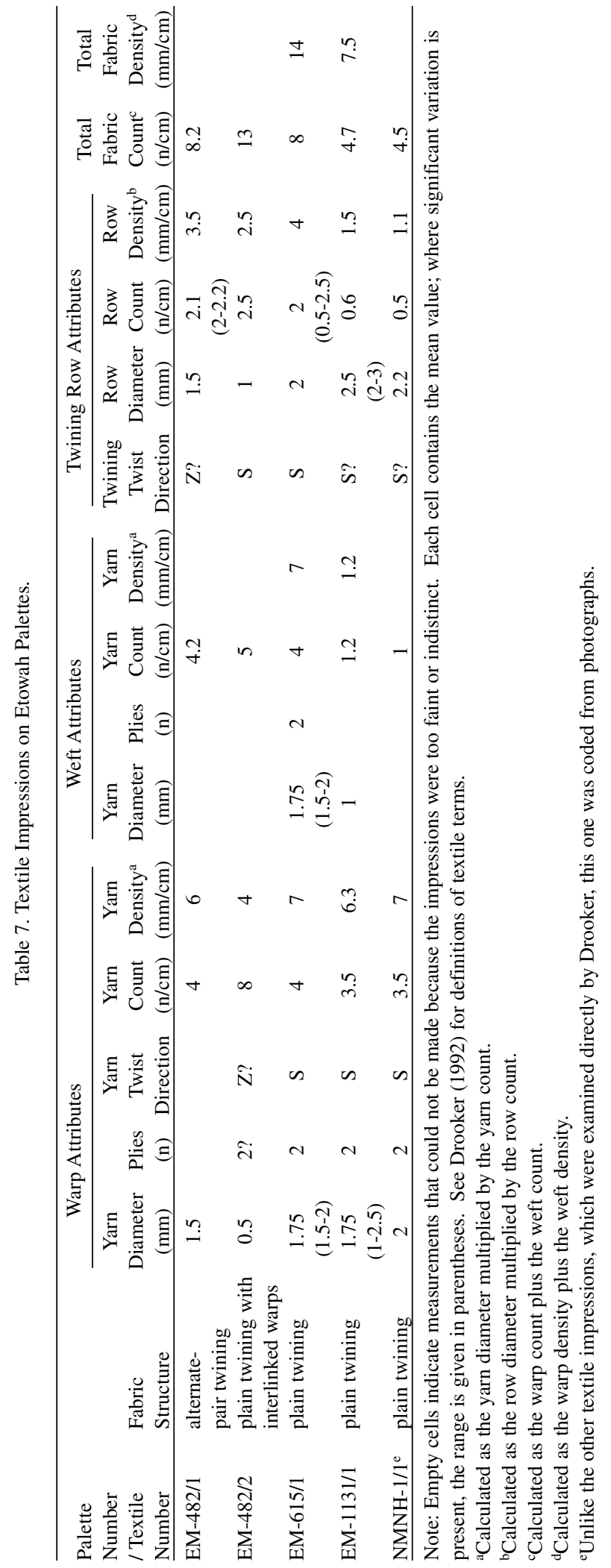


Thus, we have clear and convincing evidence that the Etowah palettes were bundled when placed in burials. The bundles also included hand-sized pebbles of metallic minerals, either galena or specular hematite, as well as various white, red, and black pigments. The implications of these findings are discussed in the section that follows.

\section{Discussion}

The distinctive style and local raw materials of the Etowah palettes indicate that they were made in northwest Georgia, probably near Etowah itself. Indeed, the consistency in style and workmanship among these palettes is such that they might all have come from the same workshop. Even so, it is uncommon to find two such palettes that are exactly alike in terms of their design and shape (see Table 2). Only one such pair occurs in our sample (NMAI-1 and NMNH-1). Apart from this one match, each of the palettes is in some way uniquebe it in the number of lines, the presence of a ridge, the shape of the profile, etc. It is as if the artists deliberately intended to make each palette recognizably different.

Turning now to matters of use, it is helpful to begin with a brief review of previous interpretations. Nineteenth-century writers were generally of the opinion that the palettes were either "plates" for holding food (Jones 1873:376; Thruston 1890:274-275) or "calendar stones" for marking the passage of time (Holmes 1883:277-279; Stoddard 1904). As mentioned previously, it was C. B. Moore who, based on the evidence from Moundville, first suggested the idea most accepted today:

The universal presence of paint upon these discs and slabs seems to offer a clue to the purpose for which they were used, and, until a better suggestion is offered, we shall consider them palettes for mixing paint [Moore 1905:147].

Soon after, W. H. Holmes, who had previously entertained the possibility that these objects were calendars, embraced Moore's idea and took it a step further. He suggested that the palettes were ceremonial in nature, and that the mixtures produced on them were valued as much for their "potency" as their color:
It is observed that these plates are made of sandstone and kindred gritty materials, and this fact confirms Mr. Moore's conclusion that they were used in grinding pigments. It is further observed that they are symmetrically shaped and neatly finished, and besides are embellished with various designs manifestly of symbolic import. That they were held in exceptional esteem by their owners is shown by their burial with the dead. These facts indicate clearly that the plates were not intended to serve merely an ordinary purpose, but rather that they filled some important sacred or ceremonial office, as in preparing colors for shamanistic use or religious ceremony. It may be fairly surmised that the pestles used in connection with these plates were also symbolic and yielded by their own attrition essential ingredients of the sacred pigments. It is a further possibility that drawings of sacred subjects were executed on the plates and, being ground off, entered also into the composition of the mixtures, imparting additional potency [Holmes 1906:105].

Statements that such palettes were for "mixing paint" or "grinding pigments" have been repeated in the literature countless times since Moore and Holmes published their interpretations (e.g., Brown 1926:231; Douglas and D'Harnoncourt 1941:87; Fundaburk and Foreman 1957:Plates 93-94; Kelly and Larson 1957:39, 43; Phillips 2006:8-9; Power 2004:98-100; Webb and DeJarnette 1942:287). Sometimes a ceremonial function has been mentioned but often it has not, thereby implying (or leaving open the possibility) that the palettes were essentially utilitarian or secular tools, albeit fancy ones. $^{4}$

That palettes were used to prepare colorful minerals for some purpose is beyond dispute. The key question boils down to purpose: were the palettes elaborate secular tools or were they ritual gear? Let us consider the evidence from Etowah.

First, the palettes are made of a polished stone that is smooth as glass. So "grinding," in the sense of rubbing minerals against an abrasive surface, was not the process used. Rather, we suspect the colorful minerals may have been crushed as in a mortar and pestle. The palette itself could have served as the mortar, and the most likely candidate for the pestle was the heavy metallic pebble, made of 
galena or specular hematite, that always accompanied the palette. This explains why only one such pebble was found with each palette, and why it was always of a size that could be used comfortably as a tool (rather than smaller flakes or crystals that would be much easier to crush). ${ }^{5}$

Second, viewing these palettes as utilitarian implements for making paint seems inconsistent with many of our observations on the residues. Why, for example, do we find unusual mixtures on the surface, such as white kaolinite with black graphite flecks (as on EM-615)? Why are the powdery pigments stratified, indicating that the palettes were not thoroughly cleaned before new colors were prepared? And how does one account for the presence of the resin? One can imagine mixing resins and mineral pigments to make paints, but why would this mixing occur on the implement used to crush the pigments, rather than in a separate vessel? And why use a pestle made of galena, a rare and visually striking mineral, when any old rock would work just as well?

All these questions become moot if the palettes were actually ritual gear, portable altars for preparing substances used in ceremonies. From this point of view, the colorful minerals were not simply pigments, but rather elements of recipes that invoked or imparted spiritual powers by virtue of their specular properties. To put it simply, the colorful minerals were important in this context for their spiritual and symbolic properties, not for their artistic or decorative ones.

Indeed, the incised and carved designs on these palettes are perfectly consistent with such an interpretation. Iconographically, they express a theme that has been called "centering" (Knight and Steponaitis 2009). In essence, the concentric lines and petaloid edge define a ritual center or axis mundi, which, in the Mississippian cosmos, was by definition a sacred place that facilitated contact with otherworldly powers (Lankford 2004, 2007). Reilly (2007a) has further suggested that a petaloid border refers explicitly to the celestial realm.

Yet by far the most compelling evidence that the palettes were ritual gear is the fact that they were kept in bundles. Throughout Native North America, bundling was the standard way of storing and transporting ritually powerful objects. Often, several such objects were bundled together in sets that were used in particular ceremonies. The groupings of palettes, metallic pebbles, and pigments at Etowah fit this pattern perfectly.

The ethnographic and ethnohistoric literature on bundles is far too extensive to fully review here (see Hanson 1980; Richert 1969; Zedeño 2008; and references therein). Although much of the published ethnographic information on bundles is from the Great Plains and western Great Lakes, it is clear that bundling was also a common practice in the Southeast. Eighteenth-century English observers referred to a bundle among Southeastern Indians as an "amulet bag" or "ark" (e.g., Moore 1988:41-43; Williams 1930:168-171, 409-410). Later ethnographers sometimes called it a "charm" or "palladium" (e.g., Hodge 1910:193-194; Mooney 1900:396-397, 429, 499; Swanton 1928:498-510, 570-576). Bundles continue to be used in traditional Southeastern Indian communities to this day (e.g., Capron 1953; Sturtevant 1954, 1960; also see Howard 1981:212-222). ${ }^{6}$

For present purposes, there are two important things to note about sacred bundles. First, they came in a variety of forms, ranging from personal bundles owned by individuals, to ceremonial bundles that were held by priests or other officials on behalf of a larger group, such as a clan or tribe. And second, most bundles, especially ceremonial bundles, could not be transferred freely as gifts. ${ }^{7}$ Rather, acquiring a bundle involved extensive preparation, often in the form of an apprenticeship, as the recipient gained the knowledge needed to use and to care for the bundle properly.

Given the first observation, it is tempting to speculate on the nature of the palette bundles at Etowah. The relatively small number of palettes and their association with elite burials in a mound suggest that these may have been ceremonial bundles connected with offices and ceremonies of community importance, rather than personal bundles. The fact that each palette was made to be recognizably different and was wrapped with a distinctive textile is consistent with this interpretation, as ceremonial bundles are sometimes said to have "personalities" and "biographies," acquired as they are used over time in ceremonies, as their contents are replenished or changed, and as they pass from one holder to another (Zedeño 2008). Equally suggestive is their distribution within the mound. The Late Wilbanks phase cemetery excavated by Larson-the only place where the palettes have 

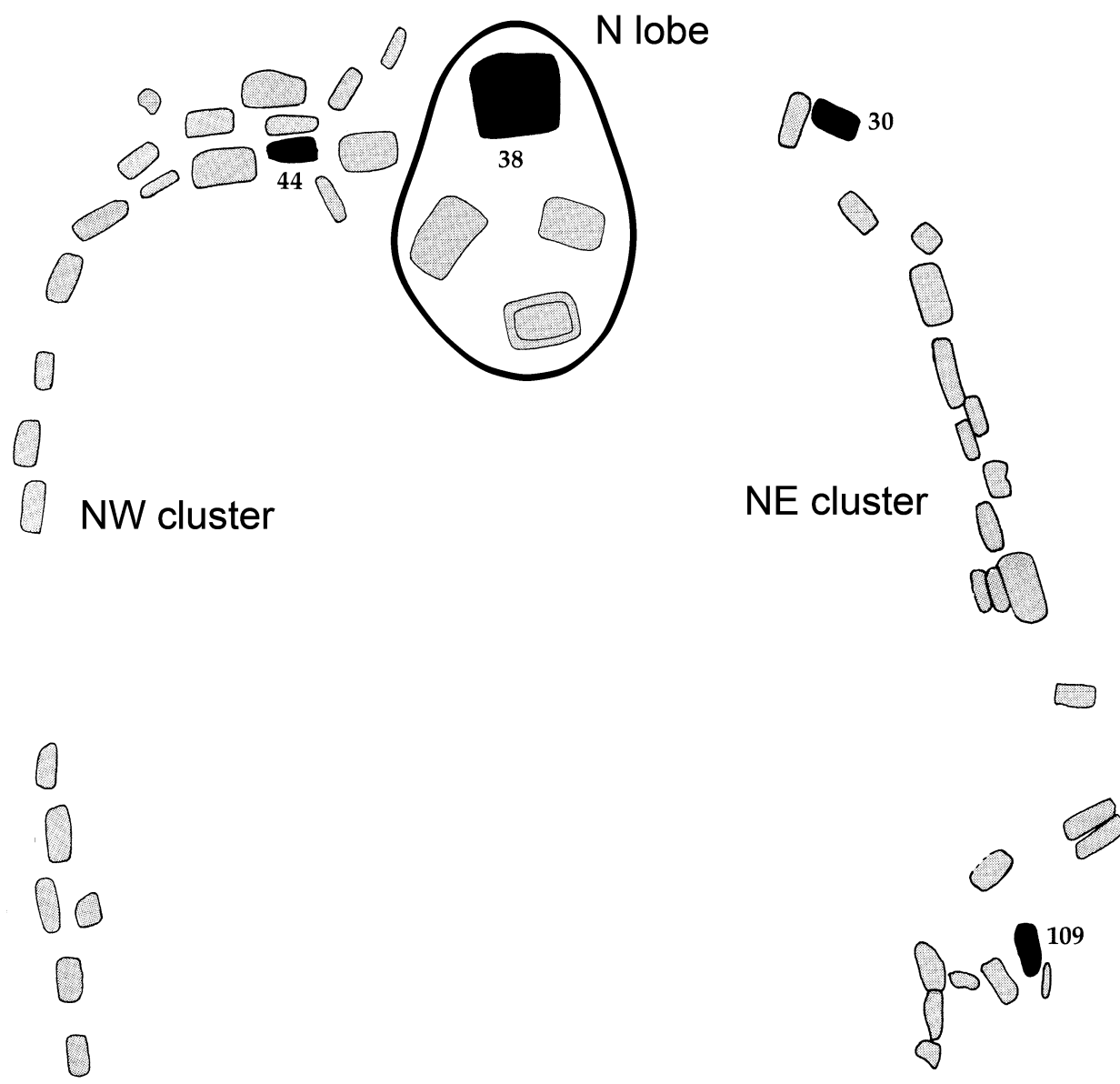

\section{SE cluster}
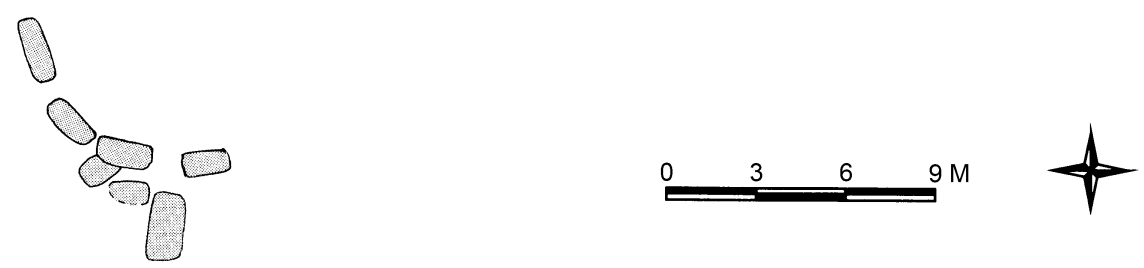

Figure 12. Distribution of burials dating to the Late Wilbanks phase at Mound C, Etowah (after King 2004:Figure 16; Brain and Phillips 1996:144). Burials with palette bundles are shown in solid black.

been found in good context - consists of a ring of burials around the base of Mound C. This ring, in turn, is divided into clearly recognizable clusters of burials: four linear groups, separated by gaps, and a fifth group underneath the mound's "northern lobe" (Figure 12). If we set aside the palette found in Burial 1, an unusual feature that seems to represent the destruction of a summit temple, the remaining four palettes show an interesting pattern. Most of the clusters contain only a single palette bundle, and none of the clusters contain more than one. In other words, there is generally a one-to-one association between burial clusters and palette bundles, the only exception being the southwest clus- 
ter which lacks such a bundle. ${ }^{8}$ King (2004:163) has suggested that such burial clusters represent "corporate kin groups or some other kind of sodality" (also see Barker 2004; Brown 2007; King 2003:77, 2009). If he is right, the spatial pattern implies that each group had its own bundle, i.e., that these bundles had corporate, rather than individual, significance.

This interpretation of the nature of the bundles raises yet another question. Because ceremonial bundles of community importance are typically passed from one generation to the next, they would not enter the archaeological record very frequently. So why were all these palette bundles "decommissioned" during the Late Wilbanks phase by being buried in Mound C? For now we have no definitive answer, but only a guess. Brain and Phillips (1996:169-170) argue that all of the Late Wilbanks burial clusters in Mound C represent "mass mortuary events" of short duration, rather than gradual accumulations over time (also see Barker 2004; Brown 2007; King 2009; Larson 1971, 2004). If this was indeed the case, then whatever circumstances triggered these events may also have warranted the decommissioning of the bundles.

Turning now to the second ethnographic observation mentioned above - that ceremonial bundles could not be freely given away-we are forced to rethink the role that palettes and similar items may have played in the political economy. For example, if an Etowah palette were to be found at a distant site (as Moundville palettes often are), ${ }^{9}$ it would be implausible to explain its presence there as the result of "trade," in the sense of barter or a simple exchange of gifts. Similarly, Etowah palettes could not have been used as tokens in a "prestige goods economy," where socially valued objects are given away by chiefs in order to cement political alliances, to buy the loyalty of followers, and to build personal prestige (Frankenstein and Rowlands 1978; Welch 1991). Simply put, bundled ritual objects could never have been treated in this manner. The palettes at Etowah were much more like the "inalienable possessions" described by Weiner $(1985,1992)$ than the "prestige goods" in Frankenstein and Rowland's (1978) model.

We have no sure knowledge of the ceremonies in which the Etowah palettes played a role, but we can speculate that they may have been used in anointing rituals, during which sacred substances were prepared on the palette, imbued with spiritual power, and then applied to people or other objects, thereby transferring that power (or its beneficial effects) to the recipients.

A nice ethnographic example of such a ritual was described by Francis La Flesche among the nineteenth-century Omaha (Fletcher and La Flesche 1911:223-251). At least once a year, the entire Omaha tribe would gather for a renewal ceremony focused on the Sacred Pole, the holiest object the tribe possessed. This ceremony required elaborate preparations, including the construction of a ceremonial lodge, and lasted several days. On the final day, the clan priests prepared a mixture of buffalo fat and red ochre while singing sacred songs, and used this mixture to anoint the Sacred Pole. The Sacred Pole was seen by the Omaha as an anthropomorphic being and was called the "Venerable Man." It was associated with a sacred bundle, which was held by a tribal priest and contained all the paraphernalia used in the ritual just described, including the red ochre and the brush used in the anointing. Portions of the Sacred Pole were heavily encrusted with red pigment, resulting from many repetitions of this ceremony (Fletcher and La Flesche 1911:Figure 51).

We do not mean to imply that exactly the same ceremony was practiced by the people at Etowah. Rather, we are suggesting that the palettes may have been used in a ceremony of the same general type. In this light, it is interesting to note that other objects found in Mound $\mathrm{C}$ at Etowah-most notably the well-known male and female stone statues found in Burial 15-are "painted" with what appear visually to be the same substances found on the palettes: red, white, and black mineral pigments, along with a yellow-brown organic resin (King 2004:Figure 6; Stuart 2004:148).

In sum, we have argued in this paper that the stone palettes at Etowah were locally produced, that they were used in rituals as portable altars, and that they were kept in sacred bundles. These findings add to the small, but growing number of cases in which bundles have been recognized archaeologically at Mississippian sites (Barker 2004; Brown 2007:238-239; Dye 2000; Reilly 2007b; Steponaitis 1991:220-221, Table 9.2; also see Ubelaker and Wedel 1975). They also add to the growing body of studies of Mississippian palettes. We 
now recognize at least two places-Etowah and Moundville-where palettes were crafted in distinctive styles and raw materials. It remains to be seen whether the palettes at Moundville were bundled, and if so, what the nature of these bundles may have been. As additional studies like this are undertaken, we predict that many other kinds of finely crafted Mississippian objects will be recognized as bundled ritual gear, rather than simply "status objects" or "prestige goods"-highly generalized categories that often convey the wrong impression of how such items were actually used and the meanings they held for the people who used them (e.g., Mills 2004). Detailed studies of the provenance and context of such objects, informed by careful attention to local ethnography and ethnohistory, have great potential to increase our understanding of the ancient Mississippian world.

Acknowledgments. We wish to thank the many individuals who facilitated our access to the Etowah collections at the various institutions where they are housed: Linda Bitley, David Crass, Ray Crook, Thomas Evans, Susan FishmanArmstrong, Jessica Johnson, James Krakker, Patricia Nietfeld, Bruce Smith, Deborah Wallsmith, and Siska Williams. James Knight and Daniel Gall accompanied us in visits to collections and helped in gathering data. Adam King and Lewis Larson were most helpful in sharing their knowledge of the Etowah site and providing guidance as we navigated the collections and field records. Tim Thompson and Emman Spain of the Cultural Preservation Office, Muscogee Nation, graciously took time to listen to the results of our research and to share their thoughts. Ellen Howe introduced the first author to the third, thereby opening the door to a nondestructive analysis of the Etowah artifacts. Alex Barker, Marc Blainey, Jeffrey Brain, Ian Brown, James Brown, Christopher Carr, David Dye, Robert Hall, David Hally, John Kelly, James Knight, George Lankford, Barbara Mills, Michael O'Hara, John Pohl, Kent Reilly, Brett Riggs, Barbara Stark, Laurie Steponaitis, George Stuart, and two anonymous reviewers provided helpful comments on earlier drafts and presentations; also helpful were the many informal conversations held at the annual gatherings of the Mississippian Iconographic Workshop at Texas State University. George Stuart and Arturo Esobar kindly took time to translate our abstract into Spanish. This research was funded in part by a project grant from the Dumbarton Oaks Research Library and Collection, Harvard University. We wish especially to acknowledge Jeffrey Quilter for his support and encouragement of our work. Preliminary results were presented in two papers at the annual meeting of the Southeastern Archaeological Conference in 2004. The senior author was greatly assisted by a Reynolds Fellowship and a Research and Study Assignment from the University of North Carolina at Chapel Hill.

\section{References Cited}

Abell, Walter

1946 Stone Disks as Treaty "Suns." American Antiquity 12(1):1-9.

Barker, Alex W.

2004 Some Preliminary Observations on the Quick and the Dead at Mound C, Etowah. Paper presented at the 61st Annual Meeting of the Southeastern Archaeological Conference, Saint Louis, Missouri. Abstract in Southeastern Archaeological Conference Bulletin 47:44.

Blakely, Robert L.

1977 Sociocultural Implications of Demographic Data from Etowah, Georgia. In Biocultural Adaptation in Prehistoric America, edited by Robert L. Blakely, pp. 45-66. Southern Anthropological Society Proceedings 11. University of Georgia Press, Athens.

1995 Social Organization at Etowah: A Reconsideration of Paleodemographic and Paleonutritional Evidence. Southeastern Archaeology 14:46-59.

Brain, Jeffrey P., Ian W. Brown, and Vincas P. Steponaitis

1995 Archaeology of the Natchez Bluffs. Manuscript on file, Research Laboratories of Archaeology, University of North Carolina, Chapel Hill.

Brain, Jeffrey P., and Philip Phillips

1996 Shell Gorgets: Styles of the Late Prehistoric and Protohistoric Southeast. Peabody Museum Press, Cambridge, Massachusetts.

Brown, Calvin S.

1926 Archeology of Mississippi. Mississippi Geological Survey, University, Mississippi.

Brown, James A.

2007 The Social House in Southeastern Archaeology. In The Durable House: House Society Models in Archaeology, edited by Robin A. Beck, Jr., pp. 227-247. Occasional Paper 35. Center for Archaeological Investigations, Southern Illinois University, Carbondale.

Capron, Louis

1953 The Medicine Bundles of the Florida Seminole and the Green Corn Dance. Anthropological Papers, Numbers 33-42. Bureau of American Ethnology Bulletin 151, pp. 155-210. Government Printing Office, Washington, D.C.

Costello, John O.

1986 Corbin Gneiss Complex: Southernmost Exposures of Grenville Basement in the Appalachian Blue Ridge. In Southeastern Section of the Geological Society of America, edited by Thornton L. Neathery, pp. 277-280. Geological Society of America Centennial Field Guide, vol. 6. Geological Society of America, Boulder.

Craig, William Blair, Jr.

1996 Etowah Site, Bartow County, Georgia, Mound C. Georgia Department of Natural Resources, Human Remains Report, Vols. 1-2. Prepared for Parks, Recreation, and Historic Sites Division, Georgia Department of Natural Resources, Atlanta.

Crickmay, Geoffrey W.

1952 Geology of the Crystalline Rocks of Georgia. Georgia Geological Survey Bulletin 58. Georgia Department of Mines, Mining and Geology, Atlanta.

Douglas, Frederic H., and René d'Harnoncourt

1941 Indian Art of the United States. Museum of Modern Art, New York.

Drooker, Penelope B.

1991 Mississippian Lace: A Complex Textile Impressed on Pottery from the Stone Site, Tennessee. Southeastern Archaeology 10:79-97.

1992 Mississippian Village Textiles at Wickliffe. University 
of Alabama Press, Tuscaloosa.

2009 Using Replication-Related Techniques to Examine the Significance of Fabrics in Mississippian Society. In Weaving Together Two Ways of Knowing: Archaeological Organic Artifact Analysis and Indigenous Textile Arts, edited by Susan Blair. Toronto University Press, Toronto, in press.

Dye, David H.

2000 The Accouterments of High Office: Elite Ritual Paraphernalia from Pickwick Basin. Paper presented at the 57th Annual Meeting of the Southeastern Archaeological Conference, Macon, Georgia. Abstract in Southeastern Archaeological Conference Bulletin 43:26.

Dye, David H., and Adam King

2007 Desecrating the Sacred Ancestor Temples: Chiefly Conflict and Violence in the American Southeast. In North American Indigenous Warfare and Ritual Violence, edited by Richard J. Chacon and Rubén G. Mendoza, pp. 160-181. University of Arizona Press, Tucson.

Dye, David H., and Camille Wharey

1989 Exhibition Catalog. In The Southeastern Ceremonial Complex, Artifacts and Analysis: The Cottonlandia Conference, edited by Patricia K. Galloway, pp. 319-378. University of Nebraska Press, Lincoln.

Elliott, Daniel T. (editor)

2006 Roland Goes to Etowah: Correspondence Pertaining to Roland Steiner's Archeological Efforts at Etowah Mounds, Bartow County, Georgia. Electronic document, http://lamarinstitute.org/rolandetowah.htm (accessed July 5, 2009).

Fletcher, Alice C., and Francis La Flesche

1911 The Omaha Tribe. Bureau of American Ethnology Annual Report 27. Government Printing Office, Washington, D.C.

Frankenstein, Susan, and Michael J. Rowlands

1978 The Internal Structure and Regional Context of Early Iron Age Society in Southwestern Germany. University of London Institute of Archaeology Bulletin 15:73-112.

Fundaburk, Emma L., and Mary D. Fundaburk Foreman (editors)

1957 Sun Circles and Human Hands: The Southeastern Indians-Art and Industries. Privately printed, Luverne, Alabama.

Gordon, Joleen

1997 Mi'kmaq Textiles: Twining: Rush and Other Fibres, BkCp-1 Site, Pictou, Nova Scotia. Curatorial Report 82. Nova Scotia Museum, Halifax.

Hanson, Jeffrey R.

1980 Structure and Complexity of Medicine Bundle Systems of Selected Plains Indian Tribes. Plains Anthropologist 25(89):199-216.

Harrington, M. R.

1914 Sacred Bundles of the Sac and Fox Indians. University Museum Anthropological Publications 4(2). University of Pennsylvania, Philadelphia.

Higgins, Michael W., Robert L. Atkins, Thomas J. Crawford, Ralph F. Crawford III, Rebekah Brooks, and Robert B. Cook

1988 The Structure, Stratigraphy, Tectonostratigraphy, and Evolution of the Southernmost Part of the Appalachian Orogen. U.S. Geological Survey Professional Paper 1475. Government Printing Office, Washington, D.C.

Hodge, Frederick Webb

1910 Handbook of American Indians North of Mexico. Bureau of American Ethnology Bulletin 30, part 2. Government Printing Office, Washington, D.C.

Holmes, William H.
1883 Art in Shell of the Ancient Americans. Bureau of American Ethnology Annual Report 2, pp. 179-305. Government Printing Office, Washington, D.C.

1906 Certain Notched or Scalloped Stone Tablets of the Mound-Builders. American Anthropologist, n.s., 8:101-108.

Howard, James H.

1981 Shawnee!: The Ceremonialism of a Native Tribe and Its Cultural Background. Ohio University Press, Athens.

Jakes, Kathryn A., and Lucy R. Sibley

1989 Evaluation of a Partially Mineralized Fabric from Etowah. Archaeometry 88:237-244.

Jones, Charles C., Jr.

1873 Antiquities of the Southern Indians, Particularly of the Georgia Tribes. D. Appleton, New York.

Kelly, Arthur R., and Lewis H. Larson, Jr.

1957 Explorations at Etowah, Georgia, 1954-1956. Archaeology 10(1):39-48.

Kesler, Thomas L.

1950 Geology and Mineral Deposits of the Cartersville District, Georgia. U.S. Geological Survey Professional Paper 224. Government Printing Office, Washington, D.C. King, Adam

2003 Etowah: The Political History of a Chiefdom Capital. University of Alabama Press, Tuscaloosa.

2004 Power and the Sacred: Mound C and the Etowah Chiefdom. In Hero, Hawk, and Open Hand: American Indian Art of the Ancient Midwest and South, edited by Richard F. Townsend and Robert V. Sharp, pp. 150-165. Yale University Press, New Haven.

2007 Mound C and the Southeastern Ceremonial Complex in the History of the Etowah Site. In Southeastern Ceremonial Complex: Chronology, Content, Context, edited by Adam King, pp. 107-133. University of Alabama Press, Tuscaloosa.

2009 Multiple Groups, Overlapping Symbols and the Creation of a Sacred Space at Etowah's Mound C. In Mississippian Mortuary Practices: Beyond Hierarchy and the Representationist Perspective, edited by Lynne P. Sullivan and Robert C. Mainfort, Jr. University Press of Florida, Gainesville, in press.

Knight, Vernon J., Jr., and Vincas P. Steponaitis

2009 A Redefinition of the Hemphill Style in Mississippian Art. In Visualizing the Sacred: Cosmic Visions, Regionalism, and the Art of the Mississippian World, edited by George E. Lankford, F. Kent Reilly III, and James F. Garber. University of Texas Press, Austin, in press.

Lankford, George E.

2004 World on a String: Some Cosmological Components of the Southeastern Ceremonial Complex. In Hero, Hawk, and Open Hand: American Indian Art of the Ancient Midwest and South, edited by Richard F. Townsend and Robert V. Sharp, pp. 207-217. Yale University Press, New Haven.

2007 Some Cosmological Motifs in the Southeastern Ceremonial Complex. In Ancient Objects and Sacred Realms: Interpretations of Mississippian Iconography, edited by F. Kent Reilly III and James F. Garber, pp. 8-38. University of Texas Press, Austin.

Larson, Lewis H., Jr.

1971 Archaeological Implications of Social Stratification at the Etowah Site, Georgia. In Approaches to the Social Dimensions of Mortuary Practices, edited by James A. Brown, pp.58-67. Memoir 25. Society for American Archaeology, Washington, D.C.

1989 The Etowah Site. In The Southeastern Ceremonial Complex: Artifacts and Analysis, edited by Patricia Galloway, pp. 133-141. University of Nebraska Press, Lin- 
coln.

1993 An Examination of the Significance of a TortoiseShell Pin from the Etowah Site. In Archaeology of Eastern North America: Essays in Honor of Stephen Williams, edited by James B. Stoltman, pp. 169-185. Archaeological Report 25. Mississippi Department of Archives and History, Jackson.

2004 The Submound and Mound Architecture and Features of Mound C, Etowah, Bartow County, Georgia. Southeastern Archaeology 23:127-141.

Lowie, Robert $\mathrm{H}$.

1915 The Sun Dance of the Crow. Anthropological Papers 16(1). American Museum of Natural History, New York.

Martin, Benjamin F., Jr.

1974 The Petrology of the Corbin Gneiss. Master's thesis, Department of Geology, University of Georgia, Athens.

Martoglio, Pamela A., Kathryn A. Jakes, and Jack E. Katon

1992 The Use of Infrared Microspectroscopy in the Analysis of Etowah Textiles: Evidence of Dye Use and Pseudomorph Formation. In Proceedings of the 50th Annual Meeting of the Electron Microscopy Society of America, edited by W. Bailey, J. Pentley, and J. A. Small, pp. 1534-1535. Microbeam Analysis Society, San Francisco.

McConnell, Keith I., and John O. Costello

1984 Basement-Cover Rock Relationships along the Western Edge of the Blue Ridge Thrust Sheet in Georgia. In The Grenville Event in the Appalachians and Related Topics, edited by Mervin J. Bartholomew, pp. 263-280. Special Paper 194. Geological Society of America, Boulder.

Mills, Barbara J.

2004 The Establishment and Defeat of Hierarchy: Inalienable Possessions and the History of Collective Prestige Structures in the Pueblo Southwest. American Anthropologist 106(2):238-251.

Miner, Horace

1936 The Importance of Textiles in the Archaeology of the Eastern United States. American Antiquity 1(3):181-192. Mooney, James

1900 Myths of the Cherokee. Bureau of American Ethnology Annual Report 19. Government Printing Office, Washington, D.C.

Moore, Alexander

1988 Nairne's Muskhogean Journals: The 1708 Expedition to the Mississippi River. University Press of Mississippi, Jackson and London.

Moore, Clarence B.

1905 Certain Aboriginal Remains of the Black Warrior River. Journal of the Academy of Natural Sciences of Philadelphia 13:124-244.

1907 Moundville Revisited. Journal of the Academy of Natural Sciences of Philadelphia 13:336-405.

Moorehead, Warren K.

1910 The Stone Age in North America. 2 vols. Houghton Mifflin, New York.

Moorehead, Warren K. (editor)

1932 Etowah Papers. Yale University Press, New Haven, for the Phillips Academy, Andover.

Phillips, Erin E.

2006 Social Status as Seen Through the Distribution of Paint Palettes, Stone Pendants, and Copper Gorgets in Moundville Burials. Master's thesis, Department of Anthropology, University of Alabama, Tuscaloosa.

Power, Susan C.

2004 Early Art of the Southeastern Indians: Feathered Serpents and Winged Beings. University of Georgia Press, Athens.

Reilly, F. Kent, III 2007a The Petaloid Motif: A Celestial Symbolic Locative in the Shell Art of Spiro. In Ancient Objects and Sacred Realms: Interpretations of Mississippian Iconography, edited by F. Kent Reilly III and James F. Garber, pp. 39-55. University of Texas Press, Austin.

2007b By Their Vestments Ye Shall Know Them: Ritual Regalia and Cult-Bearers in Mississippian Art. Paper presented at the 64th annual meeting of the Southeastern Archaeological Conference, Knoxville. Abstract in Southeastern Archaeological Conference Bulletin 50:84.

Richert, Bernhard E., Jr.

1969 Plains Indian Medicine Bundles. Master's thesis, Department of Anthropology, University of Texas at Austin.

Robinson, Brian S.

1996 A Regional Analysis of the Moorehead Burial Tradition: 8500-3700 B.P.Archaeology of Eastern North America 24:95-148.

Schreffler, Virginia L

1988 Burial Status Differentiation as Evidenced by Fabrics from Etowah Mound C, Georgia. Ph.D. dissertation, Department of Textiles and Clothing, Ohio State University, Columbus.

Sibley, Lucy R., and Kathryn A. Jakes

1994 Coloration in Etowah Textiles from Burial No. 57. In Archaeometry of Pre-Columbian Sites and Artifacts, edited by David A. Scott and Pieter Meyers, pp. 395-418. Getty Conservation Institute, Los Angeles.

Sibley, Lucy R., Kathryn A. Jakes, and Lewis H. Larson 1996 Inferring Behavior and Function from an Etowah Fabric Incorporating Feathers. In A Most Indispensable Art: Native Fiber Industries from Eastern North America, edited by James B. Petersen, pp. 73-87. University of Tennessee Press, Knoxville.

Sibley, Lucy R., Kathryn A. Jakes, and Mary E. Swinker

1992 Etowah Feather Remains from Burial 57: Identification and Context. Clothing and Textiles Research Journal 10(3):21-28.

Sibley, Lucy R., Mary E. Swinker, and Kathryn A. Jakes

1991 The Use of Pattern Reproduction in Reconstructing Etowah Textile Remains. Ars Textrina 15:179-202.

Sidoff, Phillip G.

1977 An Ethnohistorical Investigation of the Medicine Bundle Complex among Selected Tribes of the Great Plains. The Wisconsin Archeologist 58(3):173-204.

Skinner, Alanson

1913 Social Life and Ceremonial Bundles of the Menomini Indians. American Museum of Natural History Anthropological Papers 13(1).

Steponaitis, Vincas P.

1991 Contrasting Patterns of Mississippian Development. In Chiefdoms: Power, Economy, and Ideology, edited by Timothy K. Earle, pp. 193-228. Cambridge University Press, New York.

Stoddard, H. L.

1904 The Abstruse Significance of the Numbers Thirty-Six and Twelve. American Antiquarian and Oriental Journal 26:153-164.

Stuart, George E.

2004 The Education of an Archaeologist: The 1954 Season at Etowah, Georgia. Southeastern Archaeology 23:144-152.

Sturtevant, William C.

1954 The Medicine Bundles and Busks of the Florida Seminole. Florida Anthropologist 7(2):31-70.

1960 A Seminole Medicine Maker. In In the Company of Man: Twenty Portraits by Anthropologists, edited by 
Joseph B. Casagrande, pp. 505-532. Harper and Brothers, New York.

Swanton, John R.

1928 Religious Beliefs and Medicinal Practices of the Creek Indians. Bureau of American Ethnology Annual Report 42, pp. 477-672. Government Printing Office, Washington, D.C.

1946 The Indians of the Southeastern United States. Bureau of American Ethnology Bulletin 137. Government Printing Office, Washington, D.C.

Thomas, Cyrus

1894 Report on the Mound Explorations of the Bureau of Ethnology. Bureau of American Ethnology Annual Report 12. Government Printing Office, Washington, D.C.

Thruston, Gates P.

1890 The Antiquities of Tennessee and the Adjacent States. Robert Clarke, Cincinnati.

Tiedemann, E. J., and Kathryn A. Jakes

2006 An Exploration of Prehistoric Spinning Technology: Spinning Efficiency and Technology Transition. Archaeometry 48(2): 293-307.

Ubelaker, Douglas H., and Waldo R. Wedel

1975 Bird Bones, Burials, and Bundles in Plains Archaeology. American Antiquity 40(4):444-452.

Waring, Antonio J., and Preston Holder

1945 A Prehistoric Ceremonial Complex in the Southeastern United States. American Anthropologist, n.s., 47(1):1-34.

Webb, William S., and David L. DeJarnette

1942 An Archaeological Survey of the Pickwick Basin in the Adjacent Portions of the States of Alabama, Mississippi, and Tennessee. Bureau of American Ethnology Bulletin 129. Government Printing Office, Washington, D.C.

Weiner, Annette B.

1985 Inalienable Wealth. American Ethnologist 12:210-227.

1992 Inalienable Possessions: The Paradox of Keepingwhile-Giving. University of California Press, Berkeley.

Weinstein, Richard A

1984 The Rosedale and Shellhill Discs: "Southern Cult" Evidence from Southeastern Louisiana. Louisiana Archaeology 11:65-88.

Welch, Paul D.

1991 Moundville's Economy. University of Alabama Press, Tuscaloosa.

Whitehead, Ruth Holmes

1987 Plant Fibre Textiles from the Hopps Site: BkCp-1. Curatorial Report 59. Nova Scotia Museum, Halifax.

Whitney, Cynthia, Vincas P. Steponaitis, and John J. W. Rogers 2002 A Petrographic Study of Moundville Palettes. Southeastern Archaeology 21(2):227-234.

Williams, Samuel Cole

1930 Adair's History of the American Indians. National Society of the Colonial Dames of America in Tennessee, Nashville.

Williams, Stephen, and Jeffrey P. Brain

1983 Excavations at the Lake George Site, Yazoo County, Mississippi, 1958-1960. Papers 74. Peabody Museum of Archaeology and Ethnology, Harvard University, Cambridge.

Wissler, Clark

1912 Ceremonial Bundles of the Blackfoot Indians. Anthropological Papers 7(2). American Museum of Natural History, New York.

Zedeño, Maria Nieves

2008 Bundled Worlds: The Roles and Interactions of Complex Objects from the North American Plains. Journal of Archaeological Method and Theory 15:362-378.

\section{Notes}

1. Our sample includes only the well-made, decorated examples. Larson's excavations in Mound C also yielded at least three stone objects that were less formal and undecorated, called "slab palettes" in the field records (field specimen numbers 483, 693, and 982, from Burials 28, 45, and 74, respectively), but these were not included as they may have been used differently (see note 6 below). The absence of palette fragments in our sample is probably not accidental. One of us (Steponaitis) searched the Etowah collections for such fragments without success. Given the size of these collections, it is certainly possible that some were missed; but, if present, such fragments do not appear to be common. One fragment was found on the surface of the Pumpkin Vine Creek site, across the river from Etowah (George Stuart and Lewis Larson, personal communication). This object is made of Ocoee phyllite and appears to be an unfinished piece that broke in the process of manufacture.

2. Here we follow the age and sex determinations originally made by Blakely $(1977,1995)$ and compiled in the NAGPRA inventory by Craig (1996).

3. Various scholars, including one of us (Drooker), have studied the many organic textile fragments preserved in Etowah's Mound C (see Drooker 1991 [and earlier references therein], 1992, 2009; Jakes and Sibley 1989; Martoglio et al. 1992; Sibley and Jakes 1994; Sibley et al. 1991, 1992, 1996; Scheffler 1988; Tiedemann and Jakes 2006). Although a detailed comparison is beyond the scope of this paper, suffice it to say that the organic fabrics and yarns from Mound $\mathrm{C}$ burials, which probably served as garments or burial shrouds, are generally finer (thinner yarns, more yarns per centimeter) and more complex than the fabrics directly associated with the palettes. Although some of the organic fragments were comparable in scale to fabrics associated with palettes, those preserved by contact with copper artifacts were notably fine and complex.

4. Some contrarian views have also appeared in print. Moorehead (1910:1:453) expressed doubt that one such object, the so-called Almond Disk, was used for mixing paint; Waring and Holder (1945:13) were skeptical of all attempts to assign a function; and Abell (1946) suggested that palettes were in fact plaques commemorating ancient treaties. The last of these interpretations has never attracted much support. Dye and Wharey (1989:362) proposed that, in addition to "grinding paints," palettes may also have been used for the "ritual preparation of tobacco." Their suggestion is both interesting and ethnographically plausible, but there is no hard evidence to support it.

5. Once again, Holmes (1906) anticipated this interpretation by more than a century when he referred to the palettes as "mortar plates" (1906:107) and to the objects used with them as "pestles" (1906:105; see the extended quotation above).

6. It is interesting to speculate as to why the ethnographic literature on bundles is so impoverished in the Southeast, as compared to the Great Plains and western Great Lakes. Part of the answer may lie in the predilections of John Swanton, the great ethnohistorian who dominated the field of Southeastern Indian studies throughout the first half of the 
twentieth century. For whatever reason, Swanton never made a direct connection between the "bundle complex" of the Great Plains and Midwest, which had come into ethnographic focus well before 1920 (e.g., Harrington 1914; Lowie 1915; Skinner 1913; Wissler 1912), and the bundling practices of the Southeastern groups, of which he was certainly aware. Figuratively and literally, the two were kept in separate categories, i.e., "bundle" in the Plains versus "charm" or "palladium" in the Southeast, and the examples of palladia in the ethnohistoric accounts were sufficiently rare as to be only lightly treated in Swanton's encyclopedic writings (e.g., Swanton 1946:562, 692-695, 774, 819). When Swanton did describe such items in more detail, he focused exclusively on the individual objects within the bundle rather than how they were wrapped or contained in kits (e.g., Swanton 1928:498-510), with mention of the latter being purely incidental (e.g., Swanton 1928:499, 576). Interestingly, the first mentions of "bundles," as such, in the Southeastern literature appear during the 1950s, after Swanton had retired (Capron 1953; Sturtevant 1954). Other contributing factors may have been the seemingly lesser prominence that personal bundles had among Southeastern Indians, as compared to their western neighbors, and also a general (and understandable) reluctance by traditional religious practitioners to discuss these matters with outsiders (Capron 1953:159-160; Howard 1981:213; Sturtevant 1960:530-532).

7. Although Native ethnographies of the Great Plains are replete with allusions to the "purchasing" of bundles, these were not the simple, over-the-counter transactions that this unfortunate term would suggest. A closer examination of the accounts reveals that these transactions were more like apprenticeships, in which the teacher instructed the recipient in the proper treatment and use of the bundle, and the apprentice was expected to compensate the teacher with gifts (see Richert 1969; Sidoff 1977). It is also worth noting that such "purchases" were much more common in some groups than others, and also more common with personal bundles than ceremonial ones.

8. Some published compilations show a "palette" in the southwest cluster (Brain and Phillips 1996:Table 3; King 2009:Table 1), but this is one of the slab palettes described in note 1 above. If these slab palettes were included with the decorated palettes that are the focus of this study, the total would be two in the northwest cluster, two in the northeast cluster, and one each in the southeast cluster, southwest cluster, and northern lobe-still a highly symmetrical and even distribution. That said, there are reasons to suspect that the slab palettes may not have been functionally equivalent to the decorated ones. None of the slab palettes had galena or colorful minerals in direct physical contact, and only one (field specimen 483 in Burial 28) had a galena pebble and a graphite lump nearby. If these slab palettes were bundled, then the bundles were somewhat different in character. A resolution of this matter must await a detailed examination of the slab palettes and their contexts.

9. Several Moundville-style palettes, made of the distinctive gray micaceous sandstone (Whitney et al. 2002), have been found at sites in the Lower Mississippi Valley, some 300 $\mathrm{km}$ west of their source. These sites include Lake George (Williams and Brain 1983:Figure 7.41a), Glass (Brain et al. 1995), and Rosedale (Weinstein 1984). In contrast, a review of the published literature did not turn up any examples of Etowah-style palettes far from home-a result that by no means settles the question of whether such palettes ever left the Etowah area. One of us (VPS) has seen such a palette, made of a rock that looks like Ocoee phyllite, which now resides in a private collection and allegedly was found in eastern Tennessee. The reliability of the provenience, however, is subject to question.

Submitted August 31, 2009; Revised November 24, 2009; Accepted November 25, 2009. 